\title{
ARTICLES
}

\section{PROPERTY RIGHTS AND DEVELOPMENT: THE CONTINGENT CASE FOR FORMALIZATION}

\author{
MICHAEL TREBILCOCK (CORRESPONDING AUTHOR) \& \\ PAUL-ERIK VEEL*
}

\begin{abstract}
The conventional wisdom among economists and development scholars is that strong formal property rights are a necessary precondition for economic growth. By way of a thorough analysis of the theoretical and empirical literature relating to property rights and economic development, this Article questions this wisdom and argues instead for a more nuanced and contextdependent approach to the understanding of the relationship between property rights and development. The first part of this Article argues that in certain cases, the costs of creating a formal property rights regime outweigh the benefits derived from that regime. The second part argues that property rights regimes cannot be viewed as isolated institutions which are independent from other social institutions, but rather that the success of a formal property rights regime is contingent upon the successful operation of a number of other institutions. Finally, the third part examines the process of transition from an informal to a formal property rights regime and argues that the appropriate model for facilitating that transition crucially depends on the reason for the perpetuation of the informal regime.
\end{abstract}

\footnotetext{
* University of Toronto Faculty of Law. We are greatly indebted to Daniel Fitzpatrick for insightful comments on an earlier draft of this Article.
} 


\section{TABLE OF CONTENTS}

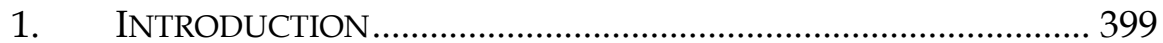

2. THE COSTS AND BENEFITS OF A FORMAL PROPERTY RIGHTS

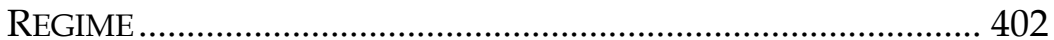

2.1. The Benefits of a Formal Property Rights Regime................ 402

2.1.1. The Benefits of Secure Property Arrangements ......... 402

2.1.1.1. Exclusive Use Leads to the Resources Being Used Efficiently

2.1.1.2. Security of Tenure and Easy Transferability of Property Increases Access to Credit. 406

2.1.1.3. Security of Tenure Increases Incentives for Investments 407

2.1.1.4. Security of Tenure Decreases Inefficient Competition for Resources .............................. 408

2.1.2. The Necessity of a Formal Property Rights Regime ... 409

2.1.3. Informal Mechanisms for Securing the Benefits of

Private Property

2.1.3.1. Game Theory Analysis

2.1.3.2. The Law and Social Norms Literature

2.1.4. Assessing the Empirical Evidence....

2.1.4.1. The Empirics of Property Rights and Efficient Use

2.1.4.2. The Empirics of Property Rights and Access to Credit.

2.1.4.3. The Empirics of Property Rights and Investment 423

2.1.4.4. The Empirics of Property Rights and

Resource Competition..

2.1.5. Property Rights and Growth: The Case of China ...... 427

2.1.5.1. Agricultural Production in Rural China ........ 427

2.1.5.2. Housing in Urban China................................. 435

2.1.5.3. The Growth of Chinese Businesses ................. 439

2.2. The Costs of a Formal Property Rights Regime.................... 443

2.2.1. Monetary Costs ..................................................... 443

2.2.2. Social Insurance and Equity..................................... 445

2.2.3. Undermining Informal Mechanisms of Tenure

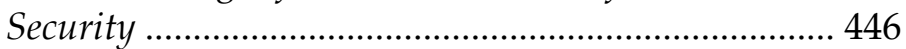

2.2.4. Social Unrest .............................................................. 448

2.2.5. The Flaws of a Titling Process................................... 450 
2.3. Concluding Remarks on the Costs and Benefits of a

Formal Property Rights Regime.

3. THE PRECONDITIONS FOR A FORMAL PROPERTY RIGHTS

REGIME

3.1. Informal Norms ................................................................. 456

3.2. The Existence of Other Markets ............................................. 461

3.3. An Effective State....

3.4. Concluding Remarks on the Preconditions of a Formal

Property Rights Regime

4. THE PROCESS OF REFORM OF PROPERTY RIGHTS REGIMES ..... 465

4.1. Evolutionary Change in Property Regimes ......................... 465

4.2. Impediments to Evolutionary Regime Change ..................... 469

4.2.1. The Property Regime as a Public Good ...................... 469

4.2.2. The Inefficiencies in Informal Regime Change ........... 470

4.2.3. A Political Economy Model of Change in Property Regimes

4.3. Responding to Evolutionary Failure: The Role of

Outsiders

4.4. Concluding Remarks on the Process of Reform of

Property Rights Regimes....

5. CONCLUSION 478

\section{INTRODUCTION}

The substantial body of economic development literature that has accumulated over the past several decades has examined a myriad of factors in seeking to provide both a descriptive account of what causes growth as well as prescriptive policies for what poor countries should do to catch up with richer states. Although few would contend that any one policy can raise the standards of living of those in the world's poorest countries to levels comparable to those in the world's richest countries, it has become conventional wisdom amongst most economists that, whatever else the state does, it should provide effective institutions and processes to protect private property rights and enforce contracts, which are regarded as pre-requisites to efficient and dynamic market economies. In the words of two prominent law and economics scholars in a forthcoming book, Law and the Poverty of Nations, "inadequate institutions to enforce property and contract law is the most pervasive and fundamental defect in the legal framework of 
poor countries." 1 On this view, law plays a critical role in promoting economic development and should be accorded the highest developmental priority. One of the Authors has examined the contract enforcement pillar of these claimed preconditions to economic growth elsewhere. ${ }^{2}$ Here, the Authors address the property rights protection pillar of this conventional wisdom.

The significance of property rights for economic growth has been the subject of much writing by development theorists and policy-makers alike. The so-called "Washington Consensus" identified property rights reform as one of the major areas of reform for the developing world. ${ }^{3}$ The World Bank has similarly highlighted the importance of property rights, and has supported and financed programs for the formalization of property rights and the creation of titling systems to secure such rights. ${ }^{4}$ While some of the research emanating from the World Bank in recent years has advocated a more nuanced approach to its policies relating to property rights and development, ${ }^{5}$ other documents have seemed to follow its traditional attitude that the formalization of property rights is virtually always desirable. ${ }^{6}$

1 Robert COOTER \& HANS-BERND SCHAEFER, LAW AND THE POVERTY OF NATIONS (forthcoming) (manuscript at 12); see also KENNETH W. DAM, THE LAW-GROWTH NeXus: The Rule of LAW AND ECONOMIC DEVELOPMENT 91 (2006) ("Proponents of the rule of law in the contest of economic development often express the core of their position... by emphasizing the need to 'enforce contracts and protect property rights.'”).

2 See Michael Trebilcock \& Jing Leng, The Role of Formal Contract Law and Enforcement in Economic Development, 92 VA. L. REV. 1517, 1518 (2006) (discussing "whether the existence of a formal contract law and enforcement regime significantly contributes to economic growth in developing countries").

3 See John Williamson, What Washington Means by Policy Reform, in LATIN AMERICAN AdJustMENT: How Much HAs HapPENED? 7, 17 (John Williamson ed., 1990) (noting property rights as an area of insecurity that needs to be corrected in Latin America).

4 World Bank, World Development Report 2005: A Better Investment Climate for Everyone, 2 (2004), available at http://siteresources.worldbank.org/INTWDR2005 /Resources/complete_report.pdf; see also Ahmed Galal \& Omar Razzaz, Reforming Land and Real Estate Markets 20-21 (World Bank Policy Research, Working Paper No. 2616, 1999), available at http://papers.ssrn.com/sol3 /papers.cfm?abstract_id=636201 (assessing the World Bank's experiences with formalizing property rights in developing nations).

5 See Klaus Deininger, Land Policies for Growth And Poverty Reduction 5-6 (2003) (finding "a considerable evolution and increased sophistication" in the recent recommendations for property reform).

6 See e.g., World Bank, supra note 4, at 80-84 (outlining measures to achieve formalization of property rights). 
Perhaps most reflective of the importance that property rights have acquired in contemporary thinking on economic development has been the success and influence of Hernando De Soto's The Mystery of Capital: Why Capitalism Triumphs in the West and Fails Everywhere Else, which argues that strong protection for private property rights is the key factor that explains the developed world's economic success. ${ }^{7}$ Indeed, on De Soto's account, the potential benefits of formalization are significant. De Soto claims that "the total value of the real estate held but not legally owned by the poor of the Third World and former communist nations is at least $\$ 9.3$ trillion," which he characterizes as "dead capital." 8

This broad assertion is unsatisfactory, however, as it leaves a great deal of indeterminacy in terms of the actual policies implied by the claim. The theoretical and empirical literature which has emerged in support of this claim has been used by some to advocate titling and registration programs as a general solution to the problem of property rights insecurity. This Article will argue that this blanket approach towards the establishment of stronger property rights is unwarranted and counterproductive. Rather, the Authors will argue that a more nuanced approach is required to craft successful development policies regarding property rights. To that end, this Article will present, and seek to provide answers to, three questions that must be asked regarding the process of strengthening property rights regimes.

First, do the benefits of formalizing property rights outweigh the costs of doing so at all stages of development? While there are compelling theoretical reasons-supported by numerous econometric studies-to believe that a number of economic benefits emerge from formal property regimes, there are also a number of economic and social costs which arise in creating and maintaining such regimes. The assumption that the benefits will always outweigh the costs is unwarranted; it is thus important to examine the conditions under which this assumption will hold. The answer to the first question also necessarily involves an examination of the form that a property rights regime might take,

7 Hernando De Soto, The Mystery of CAPITAL: Why CAPITALISM TRIUMPHS IN THE WEST AND FAILS EVERYWHERE ElSE 218 (2000); see also Madeleine Albright, It's Time For Empowerment, in THE WORLD IN 2007, at 65 (2006) (noting that property right reform is essential to economic success for the third world).

8 DE Soto, supra note 7, at 35. 
as many of the costs and benefits depend on specific aspects of the property regime in question.

Second, what social, economic, political, and legal preconditions are necessary for a formal property rights regime to function effectively? A formal property regime cannot exist in a vacuum at the state level, but rather it requires the existence of a number of complementary institutions, including an effective police force, a strong judiciary, and other similar institutions. Yet it is also important not to ignore the importance of informal norms and codes of behavior. The existence of social norms, which are not in serious conflict with the formal regime, may in fact be a precondition for an effective formal property system. Thus, it is important to understand the preconditions, both at the state and societal level, which are necessary for a formal property regime to operate as envisioned by policy-makers.

Third, how does the process of reforming property rights regimes actually occur? The answer to this question depends on the process by which property rights regimes change over time. If, as some authors have argued, property rights regimes will evolve naturally over time, then there may be a limited role for intentionally designed reforms in shaping them. By contrast, if various factors can shape this evolutionary process, then intentionally designed reforms may have a more significant role to play. Answering this question will therefore also involve an analysis of the different impediments to this evolutionary process, as well as an exploration of the differing responses that may be required.

This Article will proceed by examining each of these questions in turn, exploring both theoretical considerations as well as empirical evidence.

\section{THE COSTS AND BENEFITS OF A FORMAL PROPERTY RIGHTS REGIME}

\subsection{The Benefits of a Formal Property Rights Regime}

\subsubsection{The Benefits of Secure Property Arrangements}

Before moving to questions about the nature of an optimal property rights regime, it is first important to highlight briefly some of the reasons why property has occupied such a prominent place in the development literature in recent years. While much of 
the literature has made sweeping claims about the benefits of private property, the literature has also disaggregated the benefits by analyzing the number of distinct economic benefits which private property can bring.

Prior to outlining these separate benefits, it should be noted that it is simplistic to speak of private property rights as a whole as leading to economic growth. As many authors have pointed out, one's property over an object can typically be disaggregated into a number of rights, none of which need necessarily go together. In examining issues related to property rights and development, however, it is sufficient to use Eggertsson's aggregation of these rights into three broad categories: the exclusive right to use an asset, the right to appropriate its economic value, and the right to sell or otherwise alienate that asset. ${ }^{9}$ Indeed, most of the issues discussed below can be linked to one of these three rights.

It is also important to note that these rights are not dichotomous, but rather can exist in property to varying degrees of security. This is especially the case with the first two rights, which can be grouped together for practical purposes in the concept of tenure security. In this formulation, the stronger one's exclusive right to use and appropriate the economic value of the land, the more secure one's tenure is. Indeed, security of tenure will be used frequently below to refer to strong protection of one's exclusive rights to use and benefit from the asset in question. By contrast, tenure insecurity refers to a situation where one's claims to property are likely not to be respected. This insecurity can arise from either a) other individuals not respecting an individual's claim to his property and claiming that property as their own or otherwise encroaching on it, or b) the state not respecting an individual's claim to that land and expropriating that land. ${ }^{10}$ Having clarified some of these distinctions, some of the often-cited benefits of secure property rights will be highlighted.

9 ThrÁinn EgGERTSSON, ECONOMIC BEHAVIOR AND INSTITUTIONS 34-35 (1990).

10 See THRÁINN EGGERTSSON, IMPERFECT INSTITUTIONS: POSSIBILITIES AND LIMITS OF REFORM 182 (2005) (noting that property insecurity arises when states do not enforce a person's rights against an encroacher or from the state taking the land without compensation). 


\subsubsection{Exclusive Use Leads to the Resources Being Used Efficiently}

There are two mechanisms through which various bundles of private property rights lead to resources being used in the most efficient way possible. The first claim is that because private property leads individuals to fully internalize the costs and benefits of their use of an asset, the existence of private property will lead people to use resources in the most socially efficient way. ${ }^{11}$ When the protection of property rights over a given resource is weak, significant inefficiencies in the use and exploitation of that resource can arise. First, where numerous individuals are using the same resource, that resource may be overexploited, as individuals will not consider the detrimental effects on others from their own decisions related to resource use. ${ }^{12}$ Second, where no property rights are assigned to a resource, individuals may have an incentive to appropriate that resource as quickly as possible lest others appropriate it first; this can lead to inefficient and wasteful resource mining. ${ }^{13}$ Third, a lack of secure

11 See Harold Demsetz, Toward a Theory of Property Rights, 57 AM. ECON. REV. 347, 348-49 (1967) (discussing how private property rights force the owner of these rights to internalize the costs of their actions); see also Armen A. Alchian \& Harold Demsetz, The Property Right Paradigm, 33 J. ECON. HIST. 16, 24 (1973) (" $[\mathrm{P}]$ rivate rights can be socially useful precisely because they encourage persons to take account of social costs.") (emphasis omitted); R. H. Coase, The Federal Communications Commission, 2 J.L. \& ECON. 1, 27-35 (1959) (arguing that the use of a pricing system for the assignment of broadcast frequencies would lead to a more efficient allocation than government regulated assignments); Garrett Hardin, The Tragedy of the Commons, 162 SCI. 1243, 1245 (1968) (discussing how communal property allows people to push social costs such as pollution onto society as a whole). Proponents of new institutional economics have also examined this claim. One proponent, Douglass North, argues that private property rights raise the private rate of return of an activity closer to the social rate of return, thereby spurring economic growth. DOUGLASS NORTH, STRUCTURE AND CHANGE IN ECONOMIC HISTORY 6 (1981) ("The existence of a positive return to savings is also dependent on the structure of property rights.").

12 See ERIK FURUBOTN \& RUDOLF RICHTER, INSTITUTIONS AND ECONOMIC THEORY: THE CONTRIBUTIONS OF THE NEW INSTITUTIONAL ECONOMICS 111-16 (2d ed. 2005) (summarizing the problems that arise under common ownership of resources).

13 See Thráinn Eggertsson, Open Access Versus Common Property, in PrOPERTY Rights: CoOperation, CONFLICT, AND LAW 73, 77 (Terry L. Anderson \& Fred S. McChesney eds., 2003) ("In effect, the now-or-never motive drives actors to deplete nonrenewable resources without due attention to optimal time preferences and patterns of demand."). For a formal demonstration of this point, see Louis Hotte, Conflicts Over Property Rights and Natural-Resource Exploitation at the Frontier, 66 J. DEV. ECON. 1 (2001), who models resource use in the case of insecure ownership and shows that where landowners believe that they may lose 
property rights over a certain type of asset may lead parties to make socially suboptimal asset allocations, as they might invest in assets which have lower returns but which are easier to protect. ${ }^{14}$ Thus, these claims suggest that the stronger private property is, in the sense of private ownership and allowing individuals to capture the returns from their efforts, the greater the efficiency in the exploitation and use of a resource will be.

It is important to note, however, that under certain economic conditions, both open-access systems, where no one is excluded, and communal property arrangements, where non-members are excluded, can be economically efficient arrangements. ${ }^{15}$ For example, a system of open access to land could be a rational response to economic forces if land were not a scarce good, as in such circumstances, there is no benefit to creating formal individual property rights, while there would be a cost. ${ }^{16}$ Similarly, if land is only somewhat scarce and a community is relatively small, communal property arrangements may combine the benefits of socially efficient alternatives through collective

their access to a resource in the near future, they may exploit the resource in a socially wasteful manner.

On a related point, where individuals face tenure insecurity, they may not make socially-optimal investments for the long-term protection or sustainability of a particular resource or the environment generally because they are uncertain ex ante about their likelihood of appropriating the benefits of such investments. For example, Gebremedhin and Swinton show that the probability of farmers making long-term investments in soil conservation measures in Ethiopia was related to their perceived degree of tenure security in their land. Berhanu Gebremedhin \& Scott M. Swinton, Investment in Soil Conservation in Northern Ethiopia: the Role of Land Tenure Security and Public Programs, 29 AGRIC. ECON. 69 (2003).

14 See Stijn Claessens \& Luc Laeven, Financial Development, Property Rights, and Growth 58 J. FIN. 2401, 2402 (2003) ("[O]ur idea of property rights is the degree of protection of the return on assets against powerful competitors.").

15 See DAM, supra note 1, at 151 ("It would be a mistake, however, to conclude that all communal ownership is so inefficient that it is an obstacle to economic development."); see also Robert Ellickson, Property in Land, 102 YALE L.J. 1315, 1332 (1993) (noting the advantages of communal ownership); see generally DEININGER, supra note 5, at 29 (discussing generally some of the factors which can lead group rights to be more efficient than individual rights).

16 See Omotunde E.G. Johnson, Economic Analysis, the Legal Framework and Land Tenure Systems, 15 J.L. \& ECON. 259, 271 (1972) (arguing that in certain circumstances communal property systems allow for more cost savings than personal property). 
action with lower enforcement and transaction costs than individual property rights. ${ }^{17}$

The second mechanism through which strong property rights promote efficiency is that when the land over which one has strong private property rights is also alienable, the land can be transferred from less efficient users to individuals who will put it to more efficient uses. ${ }^{18}$ Because the land is more economically valuable to the more efficient user, mutually beneficial trades should be possible wherein land is transferred from less efficient users to more efficient users.

\subsubsection{Security of Tenure and Easy Transferability of Property Increase Access to Credit}

The linkage between property and access to credit is another economic aspect of property that has been extensively explored. Indeed, one of De Soto's main arguments in The Mystery of Capital is that secure property rights allow individuals to use their possessions as sources of capital. ${ }^{19}$ As Feder and Onchan note, creditors will be much more likely to provide credit where that credit can be secured with collateral. Property, however, whether real or personal, can only be effective collateral if creditors believe that they will be able to gain possession of this collateral in the event of the debtor's default. ${ }^{20}$ Thus, the debtor must have secure ownership of the property and have the ability to easily transfer it to the creditor.

A lack of access to credit can significantly impair economic development. Without access to credit, the requisite capital may

17 See Gershon Feder \& David Feeny, Land Tenure and Property Rights: Theory and Implications for Development Policy, 5 WORLD BANK ECON. REV. 135, 143 (1991) (discussing how voluntary collective action in a communal property arrangement enabled an efficient solution to a problem).

18 See Klaus Deininger \& Gershon Feder, Land Institutions and Land Markets 7 (World Bank Policy Research, Working Paper No. 2014, 1999) (“[T]here is some evidence that a higher degree of transfer rights provides additional incentives for investments and for more efficient use ....").

19 De SoTO, supra note 7, at 6 (noting that property rights allow Western nations to "inject[] life into assets and make[] them generate capital").

20 Gershon Feder \& Tongroj Onchan, Land Ownership Security and Farm Investment in Thailand, 69 AM. J. AGRIC. ECON. 311, 311 (1987); see also Heywood Fleisig, Secured Transactions: The Power of Collateral, 33 FIN. \& DEV. 44, 45 (1996) (discussing how enhanced land ownership security makes lenders more likely to extend credit). 
not be available to finance individuals' investments, thereby preventing individuals from making profitable investments. According to De Soto, in the United States, "up to 70 percent of the credit new businesses receive comes from using formal titles as collateral for mortgages." 21 Even where creditors do not require property as collateral, the interest rate on that credit may be higher, reflecting the higher risk which creditors face when making unsecured loans. Projects which would have been financed at the lower interest rate available for secured loans may become unprofitable or may be deemed too risky at the higher rate for unsecured credit.

It should be noted, however, that while formal title can increase the supply of credit, it may not immediately lead to greater borrowing if demand for credit is limited. Even complete security and alienability of land may not improve access to credit if landholders are risk-averse and perceive a risk of losing their land if it is mortgaged. ${ }^{22}$ This problem is especially acute when landowners have no access to insurance or alternative sources of wealth. ${ }^{23}$

\subsubsection{Security of Tenure Increases Incentives for Investment}

The increase in investment is perhaps the most discussed of the beneficial effects of strong property rights. ${ }^{24}$ There are three distinct ways in which stronger property rights can increase

21 De SoTO, supra note 7, at 84.

22 Jean-Philippe Platteau, Does Africa Need Land Reform?, in EvOLVING LAND Rights, POlicy AND TenURE IN AfricA 51, 59 (Camilla Toulmin \& Julian Quan eds., 2000). The ability to use land as collateral may actually be detrimental to smaller farmers. Eric Van Tassel's model shows that where farmers have limited income, they may not be willing to risk losing their land in order to acquire loans. Creditors, however, may be unwilling to provide unsecured loans to such farmers, as they may perceive the farmer's preference for an unsecured loan over a secured loan as indicating that the farmer poses a high risk of default. Eric Van Tassel, Credit Access and Transferable Land Rights, 56 OXFORD ECON. PAPERS 151, 151-53 (2004).

23 See Stephen R. Boucher et al., The Impact of "Market-Friendly" Reforms on Credit and Land Markets in Honduras and Nicaragua, 33 WorLD DeV. 107, 111 (2004) (indicating that "land-poor households" may be unwilling to take out loans without insurance because of the risk of collateral loss).

24 One of the most often cited papers in the contemporary literature on the theoretical and formal underpinnings of this effect is Besley's work, in which he formally models the relationship between security of tenure and investment. Timothy Besley, Property Rights and Investment Incentives: Theory and Evidence from Ghana, 103 J. POL. ECON. 903 (1995). 
investment. First, where tenure is more secure, individuals will be more likely to invest significant resources to improve their property and make it more productive. Second, where property is alienable, individuals have greater incentives to improve property because they will be able to realize a gain from that improvement upon selling it. Finally, where property is secure and alienable, the supply of credit is increased, thereby giving individuals access to the capital necessary to improve their land. ${ }^{25}$

\subsubsection{Security of Tenure Decreases Inefficient Competition for Resources}

Where property is relatively secure, two types of socially wasteful activities can be eliminated. First, where property rights are insecure, individuals may attempt to invade others' land or steal their assets for themselves. Second, and in response to this threat, individuals will have to expend resources to protect their own property from such depredations; perhaps the most destructive version of this type of private protection is the property protection provided by organized crime. ${ }^{26}$ Even where outright conflict does not occur, insecurity may induce individuals to expend resources on legal action trying to assert ownership claims to contested property. ${ }^{27}$ This reasoning implies that more secure and well-defined property may lead individuals to substitute away from unproductive conflict over property towards productive activities. $^{28}$

\footnotetext{
25 Platteau, supra note 22.

26 See Curtis J. Milhaupt \& Mark D. West, The Dark Side of Private Ordering: An Institutional and Empirical Analysis of Organized Crime, 67 U. CHI. L. REV. 41, 43 (2000) ("Organized crime... is the dark side of private ordering-an entrepreneurial response to the inefficiencies in the property rights and enforcement framework supplied by the state.").

27 See Tim Hanstad, Designing Land Registration Systems for Developing Countries, 13 AM. U. INT'L L. REV. 647, 654-55 (1998) (suggesting that uncertainty over land interests, like ill-defined boundaries, often leads to litigation, especially in the absence of effective land registration systems).

28 See Erica Field, Entitled to Work: Urban Property Rights and Labor Supply in Peru, 122 Q. J. ECON. 1561 (2007) (suggesting that formal property rights will increase household labor supply since individuals will have to spend less time informally enforcing their property claims); see also DE SOTO, supra note 7, 171-74 (arguing that formal property rights allow individuals to focus on "their assets' economic potential"); HeRnANDO De SOTO, THE OTHER PATH: THE INVISIBLE REVOLUTION IN THE THIRD WORLD 160 (June Abbott trans., 1989).
} 


\subsubsection{The Necessity of a Formal Property Rights Regime}

Many development scholars and policymakers contend that the benefits of private property described above are best achieved by a formal state-run property system. Indeed, the intellectual tradition of viewing the state as being necessary for the enforcement of claims to private property has a long genesis. ${ }^{29}$ Hobbes viewed the existence of a powerful state as necessary to overcome the anarchy that would prevail in a state of nature. ${ }^{30}$ Locke similarly viewed the primary purpose of the state as being one of protecting individuals' property, i.e. their life, liberty, and estate. ${ }^{31}$ In The Wealth of Nations, Smith viewed administering justice as an important role for government, which in part, for Smith, meant the protection of private property rights. ${ }^{32}$ Although Hume viewed property rights as conventions that all would respect for the benefit of society as a whole, he also recognized that individuals' shortsightedness might inhibit their ability to respect such conventions. He thus argued that the principal purpose of government was to overcome this short-sightedness by enforcing conventions such as property and contract. 33

A number of modern law and economics scholars have also emphasized the importance of strong property rights in economic development. Posner emphasizes the importance of developing strong property rights regimes for fostering economic growth, 34 and North suggests that strong property rights are one of the most

29 For a brief intellectual history of property rights and economics, see Edwin G. West, Property Rights in the History of Economic Thought: From Locke to J.S. Mill, in PROPERTY RIGHTS: COOPERATION, CONFLICT, AND LAW, supra note 13, at 20.

30 See Thomas Hobbes, Leviathan 189-91 (Richard Tuck ed., Penguin Books 1985) (1651) (describing a system of laws necessary to bring man out of a state of nature).

31 See John Locke, SeCOND TREATISE OF GOVERnMENT § 86-88 (Thomas P. Peardon ed., Bobbs-Merrill Co. 1952) (1690) (stating the necessity of the state for protecting private property).

32 See Adam Smith, The Wealth of Nations 901-02 (Edwin Cannan ed., Bantam Dell 2003) (1776) (describing the importance of such government functions as taxing private property).

33 David Hume, A Treatise of Human Nature, in HumE's MORAL AND POLITICAL PHILOSOPHY 69-80, 97-101 (Henry D. Aiken ed., 1962).

34 See Richard A. Posner, Creating a Legal Framework for Economic Development, 13 WORLD BANK RES. OBSERVER 1, 1 (2003) ("A modernizing nation's economic prosperity requires at least a modest legal infrastructure centered on the protection of property and contract rights."). 
important institutions for growth. ${ }^{35}$ Similarly, Knack and Keefer claim that "[f]ew would dispute that the security of property and contractual rights and the efficiency with which governments manage the provision of public goods and the creation of government policies are significant determinants of the speed with which countries grow." 36 McCloskey in discussing England's economic development states, "[i]f the word 'precondition' as it is used in the literature of economic growth includes anything it must include the formation of the legal institutions of private property ...." 37

Perhaps the best-known contemporary advocate of strong formal property rights in spurring development has been De Soto. 38 Speaking of titling, he says that "[i]t is the unavailability of these essential representations that explains why people who have adapted every other Western invention, from the paper clip to the nuclear reactor, have not been able to produce sufficient capital to make their domestic capitalism work."39 Similarly, he writes that "[t]he formal property system is capital's hydroelectric plant." 40

Although these views reflect the prevalence of the belief that formal property rights are necessary for economic development, it is important to specify why formal property rights, rather than more informal property arrangements, as discussed below, are viewed as a sine qua non of development. Formal property regimes are considered by these authors to be essential to economic growth because, when fully functional and accessible, they provide clearer and more secure allocations of property rights than could any informal measures to protect private property. ${ }^{41}$ Where there is a credible third-party enforcer of property rights - in particular, the state-"uncertainty is reduced or completely eliminated." 42

35 NORTH, supra note 11, at 6 ("The security of property rights has been a critical determination of the rate of saving and capital formation.").

36 Stephen Knack \& Philip Keefer, Institutions and Economic Performance: CrossCountry Tests Using Alternative Institutional Measures, 7 ECON. \& POL. 207, 207 (1995).

37 Donald McCloskey, The Enclosure of Open Fields: Preface to a Study of Its Impact on the Efficiency of English Agriculture in the Eighteenth Century, 32 J. EcON. HIST. 15, 16 (1972).

38 See generally DE SOTO, supra note 7.

39 Id. at 7.

40 Id. at 47.

41 See generally Johnson, supra note 16; Dam, supra note 1.

42 NORTH, supra note 11 , at 36. 
Indeed, it seems intuitive that a state-backed title registry would have the capacity to provide the most secure property rights, given the extensive adjudicative and coercive capacities that one associates with a fully-functioning state. Moreover, a formal property system can also reduce transaction costs in market interactions by providing increased information to third parties about the rights that an individual has over land. Thus, many contend that a formal property regime is necessary to provide the benefits of private property.

\subsubsection{Informal Mechanisms for Securing the Benefits of Private Property}

A formal property rights regime may not be the only method of securing the benefits discussed above. Indeed, informal mechanisms may provide many of the same benefits as a private property rights regime. Within the literature examining informal mechanisms as a substitute for formal mechanisms, there are two strands of literature that explore how this can occur. Although they are in many ways linked, they differ in some respects. ${ }^{43}$ First, the game theoretic literature explores how cooperation can emerge as a result of repeated interactions among individuals. Second, the law and social norms literature examines the development of informal norms as a mechanism of social order and control. Both of these sets of literature have strong implications for the possibility of efficient, informal property regimes, as they suggest that either spontaneous cooperation or informal norms can substitute for a formal property regime maintained by the state.

43 One important difference between the game theoretic analysis of cooperation and the law and social norms literature is that while the former supposes no order and shows how people might rationally cooperate, the law and social norms literature examines some of the negative (e.g., gossip, violence) and positive (e.g., rewards) sanctions that groups may use to enforce compliance with a norm or convention. For a survey of this point as well as a substantial list of articles which examine a variety of negative sanctions, see Richard H. McAdams \& Eric B. Rasmusen, Norms in Law and Economics (July 7, 2004) (unpublished manuscript), available at http://papers.ssrn.com/sol3/papers.cfm?abstract _id=580843 (last visited Nov. 21, 2008). Thus, while the game theoretic literature examines how rational cooperation can emerge because of repeated interactions, the law and social norms literature highlights some of the other sanctions (other than simply choosing not to cooperate in the prisoner's dilemma) that can be used to maintain order, showing how incentive structures can be changed through decentralized mechanisms. 


\subsubsection{Game Theory Analysis}

One theoretical perspective examining the conditions under which cooperation will occur is the game theoretic perspective. The prisoner's dilemma is a quintessential model of a situation in which parties must choose whether to cooperate or not cooperate with each other. While standard game theoretic models suggest that cooperative outcomes will not be achieved in a one-off prisoner's dilemma, Axelrod shows that mutually beneficial cooperative outcomes can arise in a repeated prisoner's dilemma. 44 The general requirement for cooperation is that such games continue infinitely; however, Kreps et al. show how informational asymmetries (e.g., believing for some reason that the other players have a particularly cooperative disposition) can also generate cooperation in a finitely repeated prisoner's dilemma. ${ }^{45}$ Moreover, while the models above have assumed repeated interactions between the same players, Ellison shows how even this assumption can be relaxed, as cooperation can also emerge among a small group whose members are anonymously matched in each round of the game.46 Thus, various conditions under which cooperation have emerged are in many ways relatively robust. Experimental evidence has confirmed many of these results, showing, for example, that cooperation can occur even in a finitely repeated prisoner's dilemma as individuals try to build a reputation for themselves. 47

44 Robert AXELrod, The EVOlution of COOPERATION (1984) [hereinafter AXELROD, EVOLUTION OF COOPERATION]; see also Robert Axelrod, The Emergence of Cooperation Among Egoists, 75 AM. POL. SCI. REV. 306, 307 (1981) [hereinafter Axelrod, Cooperation Among Egoists] (showing that "[w]ith an indefinite number of interactions, cooperation can emerge").

45 David M. Kreps et al., Rational Cooperation in the Finitely Repeated Prisoners' Dilemma, 27 J. ECON. THEORY 245 (1982). While the repeated prisoner's dilemma has largely been viewed as involving a number (potentially infinite) of discrete stages, some modeling has shown cooperative results to be even more robust when the model is made continuous-something which is much closer to the reality of tenure questions addressed below. See also David M. Kreps \& Robert Wilson, Reputation and Imperfect Information, 27 J. ECON. THEORY 253, 275 (1982) (arguing that uncertainty about the motivations of one or more of the players in a finitely repeated game can affect cooperation).

46 Glenn Ellison, Cooperation in the Prisoner's Dilemma with Anonymous Random Matching, 61 REV. ECON. STUD. 567 (1994).

47 James Andreoni \& John H. Miller, Rational Cooperation in the Finitely Repeated Prisoner's Dilemma: Experimental Evidence, 103 ECON. J. 570, 571 (1993). 
These principles are easily applicable to a regime of respect for property. The issue of respecting land tenure can be thought of as a prisoner's dilemma: all parties gain when tenure is respected (because of the lower costs associated with defending one's land, etc.), but each party has an incentive not to respect other parties' tenure. The exploitation of communal resources has also been viewed in this way.48 While the pessimistic predictions of the prisoner's dilemma have been used in the past to argue for a strong state to enforce order (dating back to Hobbes' Leviathan), if cooperation can emerge as discussed above, this problem can be overcome without the state's intervention. ${ }^{49}$ Rational self-interest rather than the coercive power of the state may lead parties to respect socially efficient property arrangements.

The evolutionary game theory approach also has implications for property rights considerations. Axelrod uses this approach and shows that a strategy of "tit-for-tat" (cooperation in the first round followed by playing whatever strategy the other player played in the previous round) is a collectively stable strategy. ${ }^{50}$ Axelrod also shows how a relatively small cluster of individuals playing "tit-fortat" can invade a population that is primarily comprised of defectors. In the context of property rights, this suggests a plausible mechanism for how cooperation and mutual respect can emerge and how it might be collectively stable. Cooperative play (i.e., respect for land tenure) might emerge, since even small groups which decide to respect land tenure might be more successful than those groups which do not respect tenure, and thereby come to dominate larger populations.

\subsubsection{The Law and Social Norms Literature}

In addition to the game-theoretic framework discussed above, the law and social norms literature provides an alternative explanation of how efficient property arrangements could emerge outside of a formal, legal framework. An important perspective in this line of literature is Ellickson's examination of how various informal rules can emerge which in certain circumstances make the

\footnotetext{
48 Ellickson, supra note 15, at 1388-91; Hardin, supra note 11, at 1245.

49 See Ellickson, supra note 15, at 1366 (providing a narrative of how this type of cooperation might emerge).

50 For a discussion of evolutionary stability in the biological context, see J. Maynard Smith, The Theory of Games and the Evolution of Animal Conflicts, $47 \mathrm{~J}$. THEORETICAL BIOLOGY 209 (1974).
} 
formal legal system irrelevant. ${ }^{51}$ Ellickson predicts that when social relations are close-knit, informal norms will encourage people in non-zero-sum situations to make choices that will conjoin to produce the maximum aggregate objective payoff to the group by minimizing deadweight losses and transaction costs. 52 This has led Ellickson to suggest that lawmakers should defer to these informal norms, as the norms are more likely to be welfare maximizing than centrally crafted rules. ${ }^{53}$ Epstein reaches a similar conclusion, noting that "custom should be followed in those cases in which there are repeat and reciprocal interactions between the same parties, for then their incentives to reach the correct rule are exceedingly powerful."54 These arguments imply that customary arrangements can be sufficient to generate order between parties.

Although Ellickson's theory rather optimistically predicts that such norms will emerge, it does not provide a strong explanation of the processes that determine when and why these norms emerge and why individuals adhere to them. McAdams suggests an esteem-based theory of norms, whereby a norm arises if "(1) there is a consensus about the positive or negative esteem worthiness of engaging in [an action], (2) there is some risk that others will detect whether one engages in [that action] ... and (3) the existence of this consensus and risk of detection is well-known within the population." 55 These conditions change the costs and benefits of engaging in or not engaging in an activity, and a norm will arise if the esteem benefit (cost) is greater than the benefit (cost) of (not) engaging in the activity. Eric Posner presents an alternative signaling-based model of norms, whereby social norms arise from the actions of individuals who are trying to signal to others that they are a cooperative type in order to gain benefits from

51 Robert C. Ellickson, Order Without LaW: How Neighbors Settle DisPUTES (1991) [hereinafter ELLICKSON, ORDER WITHOUT LAW].

52 Id. at ch.10. See also Robert C. Ellickson, A Hypothesis of Wealth-Maximizing Norms: Evidence from the Whaling Industry, 5 J. L. ECON. \& ORG. 83, 84 (1989) (arguing that "when people are situated in a close-knit group, they will tend to develop for the ordinary run of problems norms that are wealth maximizing").

53 ELLICKSON, ORDER Without LAW, supra note 51, at ch. 10.

54 Richard A. Epstein, International News Service v. Associated Press: Custom and Law as Sources of Property Rights in News, 78 VA. L. REV. 85, 126 (1992).

55 Richard H. McAdams, The Origin, Development, and Regulation of Norms, 96 MicH. L. REV. 338, 358 (1997). 
interactions with those individuals. ${ }^{56}$ Although the two theories have differences, they both highlight that a cooperative and welfare-enhancing norm can arise through the rational actions of a large number of individuals. Moreover, over time these norms may become internalized such that individuals might adhere to a norm even in situations where doing so might not be strictly rational. ${ }^{57}$

In the context of property, this would suggest that cooperation might be possible which would lead to the emergence of norms that yield many of the benefits that are claimed to flow from formal property rights. With respect to security of tenure, for example, this reasoning suggests that tenure security might arise among a close-knit group if this were a welfare-maximizing rule. This type of reasoning is consistent with the literature that stresses that tenure security can increase in response to increasing relative scarcity of land, since the welfare gains from secure tenure increase as the scarcity of land increases. ${ }^{58}$ Similarly, Sjaastad and Bromley have noted the presence in many African societies of a norm that dictates that when an individual loses ownership of a piece of land, the individual taking ownership must compensate the individual losing ownership for the value of improvements made to the land. 59 This norm may provide the necessary incentives to make improvements to land without some of the costs associated with greater tenure security.

It is important to note that all of the informalist theories presented above relate to property relations among individuals; none of them relate specifically with tenure security in the sense of freedom from a reasonable apprehension of expropriation of land by the state. In terms of this aspect of property ownership, it seems unlikely that an informalist would contest the fact that tenure security vis-à-vis the state is important, but the perception of

56 Eric A. Posner, Symbols, Signals, and Social Norms in Politics and the Law, $27 \mathrm{~J}$. LEGAL STUD. 765 (1998); ERIC A. POSNER, LAW AND SOCIAL NORMS 18-27 (2000) [hereinafter POSNER, LAW AND SOCIAL NORMS].

57 POSNER, LAW AND SOCIAL NORMS, supra note 56, at 43-44.

58 Gershon Feder \& Raymond Noronha, Land Rights Systems and Agricultural Development in Sub-Saharan Africa, 2 WORLD BANK RES. OBSERVER 143, 143-44 (1987) (arguing that scarcity of land encourages the development of mechanisms to secure such land); see also Demsetz, supra note 11.

59 Espen Sjaastad \& Daniel W. Bromley, Indigenous Land Rights in Sub-Saharan Africa: Appropriation, Security and Investment Demand, 25 WORLD DEV. 549, 553 (1997). 
tenure security against the state might be accomplished in a variety of ways. All that is required for this type of tenure security is that the individual not fear expropriation without compensation. To this end, predictability may be more important than formal rights.

\subsubsection{Assessing the Empirical Evidence}

Having examined the theoretical perspectives of formalists and informalists, it is important to examine the empirical evidence underlying each of these positions. A number of studies have been conducted which have broadly linked strong property rights and economic development without always specifying the causal mechanism or the particular property rights in question. While such studies are of less value in assessing or designing particular property rights regimes than are empirical studies that examine particular rights and particular benefits, they are still worth noting, if only because of their prominence in the economic development literature.

In his important paper on the determinants of economic growth, Barro asserts that strong property rights are associated with higher growth rates, although rather than using any direct measure of property rights, he uses measures of political instability and asserts a direct linkage of such indicators to property rights. ${ }^{6}$ Knack and Keefer note the problem in the Barro paper and other earlier papers of using poor proxies for property rights, and using an aggregate of a number of indicators of institutional and income quality, they find a linkage between property rights and income.61 Rodrik et al. find a link between strong property rights and growth, although they explicitly acknowledge that their results do not allow any conclusion to be drawn about the precise form of property rights that promote development. ${ }^{62}$ Similarly, Acemoglu and Johnson, using panel data from a number of countries, conclude that countries with stronger property rights-as measured by greater constraints on politicians and more protection against expropriation-have higher incomes per capita, greater investment rates, stronger credit markets, and more developed

60 Robert J. Barro, Economic Growth in a Cross-Section of Countries, 106 Q. J. ECON. 407, 431-32 (1991).

61 Knack \& Keefer, supra note 36.

62 Dani Rodrik et al., Institutions Rule: The Primacy of Institutions Over Geography and Integration in Economic Development, 9 J. ECON. GROWTH 131, 157-58 (2004). 
stock markets. ${ }^{63}$ They also find that property rights are much more important than strong contractual rights. ${ }^{64}$ Finally, a number of authors have highlighted the importance of property rights to the rapid economic growth of the Western world. 65

While these papers provide some empirical support for a linkage between strong property rights and economic growth, the ultimate implications of these results are relatively limited. These papers all support the relatively uncontroversial claim that there is a linkage between effective institutions and economic growth. However, since the authors generally use broad measures of institutional quality in their estimates rather than the degree of formalization of property rights, none of them demonstrate that legally enforceable private property rights themselves are related to economic growth, nor do they suggest anything about the precise nature of effective property rights regimes.

\subsubsection{The Empirics of Property Rights and Efficient Use}

Much more relevant for this Article than the preceding literature are those papers which attempt to link empirically formal property regimes to the specific benefits of private property discussed above. The evidence appears mixed in respect to the linkage between formal property rights and efficient use of resources. In one of the earlier studies of this type conducted in the

63 Daron Acemoglu \& Simon Johnson, Unbundling Institutions, 113 J. PoL. ECON. 949, 953 (2005) (discussing positive impact of property rights institutions on "current economic outcomes").

$64 I d$. at 987 (finding that problems that arise due to contractual relationships "are largely unrelated to political relationships and to property rights institutions").

65 De Long and Shleifer link pre-18th century European economic development with security of property rights. See J. Bradford De Long \& Andrei Shleifer, Princes and Merchants: European City Growth Before the Industrial Revolution, 36 J.L. \& ECON. 671, 679 (1993) (discussing comparatively rapid growth of cities with non-absolutist governments and, by implication, relatively strong property rights regimes). Similarly, in a less rigorous and more narrative approach to analyzing economic development, North and Thomas suggest that sustained economic growth in the West was a result of the development of private property rights. Douglass C. North \& Robert Paul Thomas, An Economic Theory of the Growth of the Western World, 23 ECON. HisT. REV. 1, 16 (1970) (arguing that development of property rights increased productivity, ultimately leading to the Industrial Revolution in Western Europe); see also DOUGLASS C. NORTH \& ROBERT Paul Thomas, The Rise of the Western World: A New ECONOMIC History 157 (1973) (hypothesizing that efficient economic organization, including property rights, was key to the growth of the Western world from 900-1700). 
developing world, Bottomley argues that the inability to capture the full returns from investment on communal land leads Libyan tribesmen to use land for animal-grazing instead of more productive and profitable almond-tree growing. ${ }^{66}$ In a classic example from Western economic history, McCloskey estimates that there were substantial efficiency gains from the enclosure movement, ${ }^{67}$ although some have disputed the magnitude of these gains. 68 These issues continue to have relevance within developed countries; for example, Flanagan and Alcantara argue that weak and highly politicized property rights regimes on Canadian aboriginal reserves are a significant impediment to efficient resource use and economic growth. ${ }^{69}$

There is also some empirical evidence indicating that insecure property rights can have a detrimental impact on businesses' investment decisions. Claessens and Laeven show that firms operating in areas of weak property rights protection will tend to have fewer intangible assets relative to tangible assets, as the latter are easier to protect from appropriation by other firms. ${ }^{70}$ Moreover, they find that this asset choice has resulted in significant inefficiencies, with stronger growth, especially among new businesses, being realized in firms located in countries with stronger property protections and relatively higher stocks of intangibles. ${ }^{71}$

In other situations, however, informal norms can result in efficient resource allocation and exploitation. In their examination of Mexico, McCarthy et al. find that the degree to which common

66 Anthony Bottomley, The Effect of the Common Ownership of Land Upon Resource Allocation in Tripolitania, 39 LAND ECON. 91 (1963).

67 McCloskey, supra note 37, at 35 (noting that enclosure produced high returns for land owners).

68 See, e.g., Gregory Clark, Commons Sense: Common Property Rights, Efficiency, and Institutional Change, 58 J. ECON. HIST. 73, 73 (1998) (arguing that "gains from enclosure existed only in the imaginations of wild-eyed eighteenth century agrarian reformers" and that, in reality, the gains from enclosure were merely modest).

69 Tom Flanagan \& Christopher Alcantara, Individual Property Rights on Canadian Indian Reserves, 29 QuEEN's L.J. 489, 530 (2004) (suggesting that increasing tracts of aboriginal land "will never yield their maximum benefit ... as long as they are held as collective property subject to political management").

70 Claessens \& Laeven, supra note 14, at 2402 (explaining preference for tangible assets in areas where property rights are weak).

71 Id. at 2423-31. Their results are particularly striking, as they appear to be robust to a number of alternative model specifications. Id. 
access land is subject to overgrazing by cattle is inversely related to the degree of cooperation between farmers, ${ }^{72}$ thereby indicating that cooperation can lead to efficient outcomes. Similarly, Katz compares two regions of Guatemala, one with a long-standing population existing with informal social norms and another that is quite new and thus lacking those social norms. These regions show that even in the absence of formal property rights, resources can be managed sustainably where there are unwritten social norms guiding their use. ${ }^{73}$ Ostrom provides a number of examples of relatively informal mechanisms for governing communal resources, thus indicating that local solutions and decision-making can result in efficient land use. ${ }^{74}$ For example, in Törbel, Switzerland, a village of only 600 people, communal space for cattle grazing is regulated by an Alp association which is governed by the villagers themselves. ${ }^{75}$ Migot-Adholla et al. similarly argue that the inefficiencies in communal land tenure in parts of Africa may be very minor. ${ }^{76}$ These examples indicate that the absence of a formal private property regime does not necessarily lead to inefficient resource use; moreover, the examples generally accord with the theoretical position of the informalists, such as Ellickson, who believe that efficient social norms are more likely to emerge where groups are relatively tight-knit and stable.

With respect to the alienability of land, it is by no means clear that a formal property regime is necessary for the development of an active land market. Some authors have argued that market-type

72 Nancy McCarthy et al., Land Allocation Under Dual Individual-Collective Use in Mexico, 56 J. DEV. ECON. 239, 262-63 (1998).

73 Elizabeth G. Katz, Social Capital and Natural Capital: A Comparative Analysis of Land Tenure and Natural Resource Management in Guatemala, 76 LAND ECON. 114, 129 (2000) (concluding that effective informal mechanisms for combating externalities and managing natural capital can evolve where more formal property rights regimes do not exist).

74 ElinOR OSTROM, GOVERNING THE COMMONS: THE EVOlution OF INSTITUTIONS FOR COLLECTIVE ACTION 58-102 (1990) (offering specific case studies which support her thesis that informal property rights managed by locals are often just as effective in regulating common-pool resources as formal regulations imposed by the outside).

75 Id. at 61-65. Ostrom also provides a number of examples of Japanese villages that created village assemblies and utilized informal sanctions to govern common lands. Id. at 65-69.

76 Shem Migot-Adholla et al., Indigenous Land Rights Systems in Sub-Saharan Africa: A Constraint on Productivity?, 5 WORLD BANK ECON. REV. 155, 172 (1991) (concluding that indigenous land rights systems are not a constraint on productivity). 
mechanisms have developed in customary law, especially where the efficiency gains from those mechanisms are highest, i.e., where land is relatively scarce. ${ }^{77}$ Indeed, extreme scarcity may result in the development of informal land markets even where market transactions are illegal, such as in Rwanda. ${ }^{78}$ If active land markets develop endogenously in response to economic incentives, this implies that a formal property rights regime is not necessarily a precondition to the development of an efficient land market.

While some authors have contended that market transfers will be inhibited without the certainty made available by formal title, in some circumstances customs have emerged which can, at least partially, substitute for formal title in creating that certainty. Jacoby and Minten, in their analysis of land in Madagascar, discuss how most land sales in rural areas were accompanied by a sales receipt which was signed by the village head, often with other witnesses present. ${ }^{79}$ This was meant to provide the buyer with certainty that the land had not already been sold to someone else and that, in the eyes of the community, the land belonged to the buyer. Informal mechanisms for land transfers have also been documented in urban housing markets. Similarly, in her study of Ho Chi Minh City, Kim finds a booming housing market, despite relatively weak formal property rights protection for most properties. She finds that neighborhood block committees and ward officials play a major role in settling disputes and providing the requisite certainty for a land market to develop. .80 Interestingly,

77 For a discussion of this phenomenon in Kenya, see Richard Barrows \& Michael Roth, Land Tenure and Investment in African Agriculture: Theory and Evidence, 28 J. MOD. AFR. STUD. 265, 269-70 (1990). Where this is the case, it may be more efficient to recognize local mechanisms of land transfer rather than try to graft Western ones onto what may be functional customary institutions. See Admos Chimhowu \& Phil Woodhouse, Customary vs Private Property Rights? Dynamics and Trajectories of Vernacular Land Markets in Sub-Saharan Africa, $6 \mathrm{~J}$. AGRARIAN CHANGE 346, 348 (2006) (arguing that effective land policies require recognition of local traditional systems of property rights).

78 Catherine André \& Jean-Philippe Platteau, Land Relations Under Unbearable Stress: Rwanda Caught in the Malthusian Trap, 34 J. ECON. BEHAV. \& ORG. 1, 42 (1998) (noting that population growth resulted in the development of informal property ownership systems).

79 Hanan G. Jacoby \& Bart Minten, Is Land Titling in Sub-Saharan Africa CostEffective? Evidence from Madagascar, 21 WORLD BANK ECON. REV. 461, 467-68 (2007) (noting that the approval by the village head serves as proof of ownership).

80 Annette M. Kim, A Market Without the 'Right' Property Rights: Ho Chi Minh City, Vietnam's Newly-Emerged Private Real Estate Market, 12 ECON. TRANSITION 275, 
using a hedonic price model, she also finds that while the added certainty of formal legal title does increase property values, this increase is relatively small: formal title increases the value of a house by 11 percent, making formal property rights more valuable than having a telephone connection but less valuable than having a toilet. 81

\subsubsection{The Empirics of Property Rights and Access to Credit}

There have also been several studies which have examined the linkage between the formalization of property rights and the availability of credit. In this respect, the evidence is somewhat mixed, although there is evidence of a linkage. It is important to note the interplay between these studies and those noted above. While title may increase the supply of credit, it may also increase the demand for credit, as landowners will desire to improve their property.

On the formalist side, Feder and Onchan show that in Thailand land title and tenure security increased access to institutional credit and thus led to greater capital formation. ${ }^{82}$ Field and Torero examine the impact of a titling program in Peru, and they find that title increased the loan approval rates from public lending institutions. ${ }^{83}$ Title did not affect the loan approval rate from private lending institutions, but conditional on receiving a loan, interest rates were significantly lower. ${ }^{84}$ The 2005 World Bank Development Report also asserts that "[f]armers with secure title in Costa Rica, Ecuador, Honduras, Jamaica, Paraguay, and Thailand obtain larger loans on better terms than those without." 85

By contrast, in the case of Nicaragua, Laiglesia finds a linkage between formal title documents and investment, but does not find

301 (2004) (discussing the role played by local officials in Ho Chi Minh City's informal property rights regime).

81 Id. at 298-99.

82 Feder \& Onchan, supra note 20, at 318-20 (identifying a correlation between possession of land title and capital formation and credit access).

83 Erica Field \& Maximo Torero, Do Property Titles Increase Credit Access Among the Urban Poor? Evidence from a Nationwide Titling Program 21 (Jan. 2004), available at http://rwj.harvard.edu/papers/field/Field percent20Do percent20Property percent20Titles percent20Increase percent20Credit....pdf (noting "strong positive relationship" between government loan approval and holding formal title to property).

84 Id.

85 World Bank, supra note 4 , at 81 . 
that to be any evidence of greater availability of credit. 86 MigotAdholla et al. similarly find no improvement in access to credit for titled land in many countries in sub-Saharan Africa. ${ }^{87}$ Johnson finds no evidence that Mexican farmers were asset-rationed out of the credit market because they did not hold title. 88 Carter and Olinto reach a more nuanced result. In their analysis of Paraguay, they find that the supply of credit is differentially available in response to stronger title, as the credit supply effects of tenure security are non-existent for small farms and only begin to become important when farms are larger than fifteen hectares. ${ }^{89}$

Where informal credit markets exist and at least partially substitute for the formal credit market, it seems that the importance of title is significantly diminished. Pamuk examines how informal credit arrangements emerged in Trinidad, which serve the large section of the population without formal title..$^{90}$ Similarly, André and Platteau describe how mortgages were readily available in Rwanda from informal credit associations known as tontines, which had sufficient authority to seize the debtor's lands in the event of a default, despite the absence of formal title. ${ }^{91}$ Even Feder and Onchan, who are otherwise staunch defenders of the theory that formal property rights can increase access to credit, acknowledge that their evidence shows that the impact of formal property rights on access to credit was negligible in one Thai province which already had a well-developed informal credit market. ${ }^{92}$

86 Juan R. de Laiglesia, Investment and Credit Effects of Land Titling and Registration: Evidence from Nicaragua 22 (Research Comm. Dev. Econ., Working Paper No. 10, 2005), available at http://opus.zbw-kiel.de/volltexte/2005 /3483/pdf/De_Laiglesia.pdf.

87 Migot-Adholla et al., supra note 76.

88 Nancy L. Johnson, Tierra y Libertad: Will Tenure Reform Improve Productivity in Mexico's Ejido Agriculture? 49 Econ. Dev. Cultural Change 291, 304 (2001).

89 Michael R. Carter \& Pedro Olinto, Getting Institutions "Right" for Whom? Credit Constraints and the Impact of Property Rights on the Quantity and Composition of Investment, 85 AM. J. AgRIC. ECON. 173, 184 (2003).

90 Ayse Pamuk, Informal Institution Arrangements in Credit, Land Markets and Infrastructure Delivery in Trinidad, 24 INT'L J. URBAN REG'L RES. 379, 381-89 (2000).

91 André \& Platteau, supra note 78, at 21.

92 Feder \& Onchan, supra note 20, at 315. 


\subsubsection{The Empirics of Property Rights and Investment}

As with the above considerations, the evidence linking formal property rights to increased investment is mixed. On the one hand, there are a number of studies in various settings which suggest that formal property rights lead to increased investment. ${ }^{93}$ On a broad level, in a cross-country regression analysis, Svensson finds that countries with stronger property rights had higher investment rates. ${ }^{94}$ On a more micro level, Besley finds some support for the linkage between investment and property rights in Ghana. ${ }^{95}$ Similarly, Alston et al., in their analysis of land in the Brazilian Frontier, conclude that title increases farm-specific investment as well as land value. ${ }^{96}$ In his analysis of Guatemala, Schweigert, after controlling for the availability of credit, found that households with formal title generated greater output and invested more family labor towards generating future production. ${ }^{97}$

93 The linkage between formal property rights and investment presumes the existence of a relationship between tenure security and investment, as the benefit of formal property rights is that they are presumed to increase tenure security. While the latter relationship has generally been found to be strong, not all studies have found evidence of a strong relationship, at least where the investments are relatively short-term. See Stein Holden \& Hailu Yohannes, Land Redistribution, Tenure Insecurity, and Intensity of Production: A Study of Farm Households in Southern Ethiopia, 78 LAND ECON. 573, 583-87 (2002) (finding no evidence of a relationship between perceived tenure security and the use of farm inputs in their study of southern Ethiopia). Thus, in some cases the question of the degree of tenure security may not have a significant impact on investment. However, while this may be true at the margins, it seems theoretically implausible and empirically incorrect to suggest that there is, at least at a broad enough level, no relationship between tenure security and investment. In the extreme case, an individual who knows with certainty that their property will be appropriated without compensation tomorrow obviously has no incentive to make an investment that will only provide a pay-off a week in the future.

94 Jakob Svensson, Investment, Property Rights and Political Instability: Theory and Evidence, 42 EUR. ECON. REV. 1317, 1336-37 (1998).

95 Besley, supra note 24, at 936.

96 Lee J. Alston et al., The Determinants and Impact of Property Rights: Land Titles on the Brazilian Frontier, 12 J. LAW ECON. ORG. 25, 57-58 (1996).

97 Thomas Schweigert, Land Title, Tenure Security, Investment, and Farm Output: Evidence from Guatemala, 40 J. DEV. AREAS 115, 123 (2006). In an analysis of tenure reform in West Bengal, Banerjee, Gertler, and Ghatak find that a government registration program designed to guarantee sharecropper tenure significantly increased agricultural productivity. While they speculate that a major reason for this increase was that the increased security gave sharecroppers appropriate incentives to invest in the land, their model did not allow for a precise investigation of the causal mechanism linking increased tenure security and 
While most of the above studies have focused on security of tenure in the agricultural context, there is similar evidence linking tenure security to investment in urban settings. Field finds that investment in housing increased significantly once title was issued to slum-dwellers in Peru. She finds that this effect is independent of increased access to credit, because there were similar increases in investment among both those who received credit as well as those who were rationed out. 98 Struyk and Lynn reach a similar conclusion in their analysis of housing investment in Manila. ${ }^{99}$ However, measures other than tenure formalization may also play a major role in improving investment incentives. For example, Varley argues that the provision of government services to informal urban settlements can be an adequate substitute for actual formalization programs, as both have the effect of increasing perceived security of tenure. 100

The investment decisions of firms may also be significantly altered by the perceived security of property rights. For example, in their examination of reinvestment rates of firms' profits in different countries in the former Eastern bloc, Johnson, McMillan and Woodruff found that entrepreneurs reinvested less of their retained earnings when they perceived their property rights to be less secure. ${ }^{101}$

While the expectation of tenure security is almost certainly linked to increased investment, mechanisms other than formal title can in some cases be used to achieve that tenure security. For example, Lanjouw and Levy find that while formal title increases tenure security and the value of the land, they also find that informal mechanisms can effectively substitute for those in certain

increased productivity. Abhijit V. Banerjee et al., Empowerment and Efficiency: Tenancy Reform in West Bengal, 110 J. POL. ECON. 239, 240 (2002).

98 Erica Field, Property Rights and Investment in Urban Slums, 3 J. Eur. ECON. Ass'N. 279, 280-81 (2005).

99 Raymond J. Struyk \& Robert Lynn, Determinants of Housing Investment in Slum Areas: Tondo and Other Locations in Metro Manila, 59 LAND ECON. 444, 453 (1983).

100 Ann Varley, The Relationship Between Tenure Legalization and Housing Improvements: Evidence from Mexico City, 18 DEV. \& CHANGE 463 (1987).

101 Simon Johnson et al., Property Rights and Finance, 92 AM. ECON. REV. 1335, 1336 (2002). Cull and Xu conducted similar research in China and reached broadly similar results. Robert Cull \& Lixin Colin Xu, Institutions, Ownership, and Finance: The Determinants of Profit Reinvestment Among Chinese Firms, 77 J. FIN. ECON. 117, 117 (2005). 
situations. ${ }^{102}$ Both the increasing age of the community (indicative of greater time for social norms to develop) and paying a community organizer (a decentralized social order mechanism) were found to reduce the value of title. Lanjouw and Levy thus suggest that titling programs should be focused on new and disorganized communities. Similarly, Brock examines customary land tenure in Uganda and finds that in most parts of the country, land tenure is relatively secure under customary law; at the very least, customary law has not impeded the planting of coffee, which is a long-term cash crop requiring the expectation of relatively secure tenure. ${ }^{103}$ This suggests that the appropriate question in determining whether a property regime gives efficient investment incentives is not simply whether the property rights regime is a formal or informal regime, but rather whether there are mechanisms in place to provide property owners with a sufficient perception of security to encourage efficient investment.

Moreover, the interpretation of the above papers - that formal property leads to higher investment levels - must be made with some caution, as there are some papers which seem to suggest that the causality between formal property rights and investment may be reversed. There are two mechanisms through which this may operate. First, it may be the case that investments in land are actually made as a mechanism for improving tenure security rather than as a result of it. Razzaz examines squatter settlements in Jordan and concludes that parties would invest in their properties in order to gain de facto property rights, since the state would be less likely to demolish completed houses. ${ }^{104}$ Second, it may be the case that individuals seek out greater tenure security once their property is more valuable or they have made more investments, rather than the reverse. In these circumstances, an endogeneity

102 Jean O. Lanjouw \& Philip I. Levy, Untitled: A Study of Formal and Informal Property Rights in Urban Ecuador, 112 ECON. J. 986, 986 (2002).

103 B. Brock, Customary Land Tenure, 'Individualization', and Agricultural Development in Uganda, 2 E. AFR. J. RuRAL DEV. 1 (1969). It is important to note that even within customary property regimes, there may be significant differences in the perception of tenure security. In their study of agricultural investment in the Gambia, Hayes et al. find that differences in landowners' perceptions of their rights over their land in customary law statistically and significantly impacted their levels of investment in their land. Joseph Hayes, Michael Roth \& Lydia Zapeda, Tenure Security, Investment and Productivity in Gambian Agriculture: A Generalized Probit Analysis, 79 AM. J. AGRIC. ECON. 369, 381 (1997).

104 Omar M. Razzaz, Examining Property Rights and Investment in Informal Settlements: The Case of Jordan, 69 LAND ECON. 341, 352-53 (1993). 
bias may inflate the estimated impact of title on investment in many studies. Antle et al. show that the positive effect on investment decisions of titling are smaller when simultaneous equations are used than single-equation models, which is consistent with the idea that the causality is reversed. 105 Brasselle et al. similarly find that once the endogeneity bias is controlled for, increased land rights do not significantly increase investment. 106

\subsubsection{The Empirics of Property Rights and Resource Competition}

Although research in this area is limited, there does seem to be cases of individuals and groups in an environment of insecure property rights undertaking activities solely for the purpose of protecting their property. As noted above, Razzaz describes how squatters would attempt to erect permanent structures extremely quickly between state bulldozing of their settlements. ${ }^{107}$ An even more striking example of such an activity is examined by De Vany and Sanchez, who examine the fertility decisions of ejiditarios [residents and members of an ejido] living on communal ejidos [lands farmed by cooperatives] in Mexico. They find evidence of greater fertility among ejiditarios than among other landowners, and they posit that those families choose to have more children because of several advantages which children provide in terms of securing larger property plots for those families. ${ }^{108}$ Although it is difficult to estimate or quantify the inefficiencies resulting from the above activities, they do show the existence of expenditures made for the protection of property claims. Thus, insecure property rights may lead to socially excessive investments, as individuals use scarce resources on costly measures to attempt to enforce property claims.

One attempt to quantify the magnitude of this inefficiency has been undertaken by Erica Field in her examination of the effects of

105 John Antle et al., Endogeneity of Land Titling and Farm Investments: Evidence from the Peruvian Andes (Aug. 2003) (working paper, on file with the Montana State University Department of Agricultural Economics and Economics) available at http:/ / www.tradeoffs.montana.edu/pdf/titling.pdf.

106 Anne-Sophie Brasselle et al., Land Tenure Security and Investment Incentives: Puzzling Evidence from Burkina Faso, 67 J. DEV. ECON. 373, 375 (2002).

107 Razzaz, supra note 104.

108 Arthur De Vany \& Nicolas Sanchez, Land Tenure Structures and Fertility in Mexico, 61 REV. ECON. \& STAT. 67, 67-68 (1979). 
the titling program in urban Peru. Her study focuses on quantifying the degree to which insecure tenure forces households to spend time guarding their residences instead of working. She finds that, after controlling for a variety of factors, newly-titled households worked on average forty-five hours per week more than non-titled households. ${ }^{109}$ Although one of the few studies of its kind, Field's work provides preliminary support for believing that secure property rights may increase labor market participation.

\subsubsection{Property Rights and Growth: The Case of China}

China is an important case study in the examination of the relationship between protection of property rights and economic development, given that it has achieved dramatic rates of economic growth despite weak formal property rights protection. Moreover, because of the sheer size and diversity of China as well as significant temporal and geographic variation in its policies, China provides an excellent example of many of the issues highlighted above. Because of its importance and its recent record of economic growth, the case of China will be referred to throughout this Article. This Section will examine many of the issues discussed above in the context of three different aspects of economic activity in China: rural land and agricultural production; urban housing markets; and private enterprises.

\subsubsection{Agricultural Production in Rural China}

In the years following the Chinese Revolution, the Chinese government instituted massive social changes that significantly impacted the agricultural sector. Private property in rural land was effectively abolished by 1956, and rural agricultural production was organized around communes or collectives. ${ }^{110}$ These changes provided rural inhabitants with limited incentives to work and failed to increase agricultural production, as individuals and families could not realize the benefits of increased labor or investment. Similarly, because there were monitoring costs for production team managers and such supervision was consequently imperfect, there were limited penalties that

109 Field, supra note 28, at 36.

110 Samuel P.S. Ho \& George C.S. Lin, Emerging Land Markets in Rural and Urban China: Policies and Practices, 175 CHINA Q. 681, 682-83 (2003). 
accompanied limited effort. ${ }^{111}$ Unsurprisingly from the perspective of property rights formalists, grain production grew relatively slowly between the early 1950s and the late 1970s.

This situation was altered dramatically with the introduction of the Household Responsibility System (HRS) in the early 1980s. Under the HRS, while the collective retained legal ownership of the land, contracts were provided to farmers and their families to give them use rights over the land through long-term leases. The initial term of these leases were for five years, but the term was extended to fifteen years in 1984 and then thirty years in 1993.112 Tenure security was further strengthened in the 1998 revision of the Land Administration Law (also called the Land Management Law), which provided for thirty-year leases with strong restrictions on when readjustments could be made.113 In 2002, the Rural Land Contracting Law was passed, which strengthened farmers' rights by not only prohibiting land readjustments in all but the most exceptional cases, but also by requiring the execution of written contracts between the collective and farmers which spelled out farmers' rights. ${ }^{114}$ A new property law passed in 2007 further strengthened land tenure by giving farmers the right to renew their thirty-year leases upon expiry of the lease. ${ }^{115}$ Most recently, proposals put forward in October 2008 seek to reinforce private property rights by further strengthening tenure and by making it easier for farmers to transfer their land.116

111 Justin Lin, The Household Responsibility System in China's Agricultural Reform: A Theoretical and Empirical Study, 36 ECON. DeV. \& CUltural CHANGE S199, S206-08 (1988).

112 Peter Ho, Institutions in TRANSITION: LAND OWNERShIP, PROPERTY Rights, AND SOCIAL CONFLICT IN CHINA 6 (2005).

113 Land Administration Law (promulgated by the Standing Comm. Nat'l People's Cong., Aug. 29, 1998, effective Jan. 1, 1999), art. 14, LAWINFOCHINA (last visited Nov. 21, 2008) (P.R.C.) [hereinafter Land Administration Law, 1998]; Ho \& Lin, supra note 110.

114 Law on Rural Land Contracting (promulgated by the Standing Comm. Nat'l People's Cong., Aug. 29, 2002, effective Mar. 1, 2003) LAwINFOCHINA (last visited Nov. 21, 2008) (P.R.C.); Zhu Keliang et al., The Rural Land Question in China: Analysis and Recommendations Based on a Seventeen-Province Survey, 38 N.Y.U. J. INT'L L. \& POL. 761 (2006).

115 Property Law (promulgated by the Nat'l People's Cong., March 16, 2007, effective October 1, 2007) LAWINFOCHINA (last visited Nov. 21, 2008) (P.R.C.) [hereinafter Property Law]; Caught Between Right and Left, Town and Country, ECONOMIST, Mar. 8, 2007.

116 Land Reform in China: Still Not to the Tiller, ECONOMIST, Oct. 23, 2008. 
Although rural land rights have significantly varied over time and between regions, ${ }^{117}$ some generalizations are possible regarding the nature of the Chinese agricultural property regime. On the one hand, these formal use rights fall short of the full bundle of rights which most formalists advocate. For example, although farmers have options regarding the cultivation of their land, they are not permitted to convert the land to non-agricultural use; this may impede the realization of certain potential efficiency gains. Furthermore, the mortgaging of farmland continues to be prohibited, thereby constraining the supply of rural credit. ${ }^{118}$

On the other hand, these use rights seem to provide many of the protections that are associated with formal private property rights regimes. Most importantly, subject to the conditions above as well as certain implicit and explicit taxes, use rights are intended to be relatively secure. Land markets are also theoretically facilitated by these use rights, as they are transferable in a variety of ways, including inheritance and lease.119 Land transfers within the collective were formally permitted by the 1986 Land Administration Law, and in 1998 amendments to the Land Administration Law allowed for contracting of the land to those outside the collective, provided a sufficient proportion of the collective consented. ${ }^{120}$ Thus, even if formal ownership rests in the collective, the legal framework of use rights seemingly provides sufficiently strong claims to individuals to yield many of the advantages of private property discussed above by the formalists.

There are, however, four reasons why even the formal use rights held by rural Chinese would fail in practice to provide many of the posited benefits of private property. First, administrative redistribution of land by the village leadership is common, leading to decreased tenure security. A 2005 survey found that 74.3 percent of villages had conducted at least one land redistribution since the implementation of the HRS, while 55.0 percent of villages had experienced two or more readjustments. ${ }^{121}$ This occurs most

117 Charles Krusekopf, Diversity in Land Tenure Arrangements Under the Household Responsibility System in China, 13 CHINA ECON. REV. 297, 298-301 (2002).

118 ECONOMIST, supra note 115.

119 Weiguo Wang, Land Use Rights: Legal Perspectives and Pitfalls for Land Reform, in DEVELOPMENT DileMmAs: LAND REFORM AND INSTITUTIONAL CHANGE IN CHINA 62 (Peter Ho ed., 2005).

120 Land Administration Law, supra note 113, art. 15; Ho \& Lin, supra note 110.

121 Keliang et al., supra note 114 , at 775. 
often in response to demographic changes, such as changes in household size or labor supply. ${ }^{122}$ Although the central government has issued directives against such redistribution and occurrences of such redistribution have been decreasing, it remains widespread. ${ }^{123}$ This may be the result of a continued perception by many of land as a communal resource.124 Thus, given the significant deviation between formal law and informal norms, it is possible that the latter has undermined the former.

Second, especially in rural areas near towns and cities, there is a significant risk of expropriation of rural land for development, also decreasing tenure security. The Chinese constitution specifically allows the state to expropriate collective land - a power that local officials have seemed to exercise with some frequency. ${ }^{125}$ Keliang et al. find that the number of expropriations of rural farmland increased fifteen-fold between 1995 and 2005.126 Moreover, this expropriation often occurs without real consultation, and the compensation provided is significantly less than either the market value of the land or the amount needed to compensate farmers for the loss of their livelihoods.127 Even this meager compensation is sometimes not provided. Keliang et al., for example, find that only two-thirds of farmers actually received compensation that was promised to them in return for expropriation. 128

Third, while land transfers are formally permissible, there continue to be barriers to the development of an active market for land. These include cultural taboos related to the commoditization

122 Loren Brandt et al., Land Rights in China: Facts, Fictions and Issues, 47 CHINA J. 67, 70 (2002).

123 Wang, supra note 119. Indeed, Krusekopf suggests that the village leader, rather than the central government, is the ultimate determiner of land relations in a given village. Krusekopf, supra note 117.

124 James Kung, Choice of Land Tenure in China: The Case of a County with QuasiPrivate Property Rights, 50 ECON. Dev. \& Cultural Change 793, 794 (2002).

125 Prior to 2004, the Chinese constitution permitted expropriation without compensation. Amendments introduced in 2004 require the payment of compensation for any land expropriated or requisitioned. Compare XIAN FA art. 10 (1982) (P.R.C.) with XIAN FA art. 10 (2004) (P.R.C.) (demonstrating the changes made to the constitution regarding land expropriation and related compensation); Ho \& Lin, supra note 110.

126 Keliang et al., supra note 114 , at 780.

127 Xiaolin Guo, Land Expropriation and Rural Conflicts in China, 166 CHINA Q. 422, 423 (2001).

128 Keliang, supra note 114 , at 782. 
of land, the perception of the need for land as a form of social insurance, and, in some areas, local prohibitions on the transfer of land, despite its formal legality at the national level.

Finally, and more generally, rural peasants are generally unable to access the legal system to enforce their rights. The court system is largely out of reach of rural farmers, and in many cases no written contracts or certificates were issued to farmers detailing their entitlements to the use of a certain plot of land. ${ }^{129}$ Keliang et al. find that, as of 2005, 36.8 percent of households had neither a contract nor a certificate which provided written evidence of their land rights. ${ }^{130}$ Potentially more disturbing is the poor quality of these documents: only 10.4 percent of farmers possessed either a contract or certificate which fully outlined their rights and contained all the contractual provisions required by the legislative and regulatory framework. ${ }^{131}$ As a result, there is often a significant divergence between the formal rights and entitlements of farmers and the treatment they receive from local officials.

While the transition from communal agricultural production to the HRS brought significant growth in grain production, scholars supporting a formal property rights regime predict that such growth would be limited by continuing tenure insecurity. Although grain production rose dramatically in the early 1980s this growth being largely attributed to the incentives that were created by allowing farmers to internalize the benefits of increased yields - growth began to slow in the mid-1980s; from 1985 to 1994, grain output increased only 0.9 percent annually. ${ }^{132}$ Some scholars have sought to explain the slowdown in the growth of grain in the mid-1980s by arguing that the efficiency gains resulting from partial privatization and increased labor input had been exhausted and that further growth would require increased physical inputs to agricultural production. ${ }^{133}$ Thus, while the internalization of benefits associated with increased investment in labor and other

129 RANDAll PeEREnboOM, ChinA's LONG March TOWARd Rule OF LAW 483 (2002); see also id. ch. 7 (outlining general commentary on the inadequacies of the judiciary).

130 Keliang et al., supra note 114 , at 788.

131 Id. at 789.

132 Brandt et al., supra note 122, at 68.

133 Gershon Feder et al., The Determinants of Farm Investment and Residential Construction in Post-Reform China, 41 ECON. DeV. \& Cultural CHANGe 1, 1-2 (1992). 
inputs had increased production to a point, further production increases would require additional investment. They predicted that tenure insecurity would dissuade farmers from making such investments, especially those investments which had a relatively long time-horizon.

Such analysis is challenged by some authors, however, who contend that agricultural production continued to be strong despite weak property rights. These authors suggest that agricultural growth remained strong through the 1980s, with the stagnation in grain output largely caused by farmers switching away from grain in favor of higher-valued crops. ${ }^{134}$ Moreover, in the late 1990s, the rate of growth of grain production began to accelerate again, and agricultural output has seen substantial growth in recent years; this is consistent with the above reasoning, as the government relaxed its price controls on grain in the early 1990s, thereby increasing the incentives for farmers to produce it. ${ }^{135}$ Indeed, rural economic growth throughout this period seems to have been strong, with one author noting that real per capita net income of rural residents rose by 63 percent between 1985 and 1997.136 Because of this seemingly unusual growth in the presence of weak property rights, it is essential to examine the empirical research which has been undertaken to determine what the relationship is between security of tenure and agricultural growth in the Chinese context.

Perhaps unsurprisingly, the empirical record linking agricultural output and security of tenure in China is mixed. On the one hand, much of the empirical work has shown a linkage between increased investment and stronger perceptions of tenure security. Li, Rozelle, and Brandt, using the length of time which a farmer has occupied a plot of land as a proxy for tenure security, found that increased tenure security increases incentives for longterm land-saving investments, though not for short-term investments. ${ }^{137}$ Deininger and Jin reach a similar result in

134 David K. Lambert \& Elliot Parker, Productivity in Chinese Provincial Agriculture, 49 J. AGRIC. ECON. 1, 16 (1998).

135 Id. (1999).

136 Jean C. Oi, Two Decades of Rural Reform in China, 159 CHINA Q. 616, 616

137 Guo Li et al., Tenure, Land Rights, and Farmer Investment Incentives in China, 19 AgRIC. ECON. 63, 65 (1998); see also Hanan Jacoby et al., Hazards of Expropriation: Tenure Insecurity and Investment in Rural China, 92 AM. ECON. REV. 1420, 1421-22 
comparing Guizhou, a Chinese province which adopted a policy of not redistributing land in response to demographic changes, with other provinces which otherwise shared many similar characteristics. ${ }^{138} \mathrm{Hu}$ has similarly argued that the short time horizons provided by the current land tenure system have led to the presence of short-term resource mining and environmental degradation. ${ }^{139}$ While none of these studies could address the impact of formal title to land, they do indicate that increased perceptions of security led to greater investment. The logical conclusion of these arguments is that the increased security provided by formal title would bring even greater benefits in terms of investment, long-term planning, and resource management. Indeed, Keliang et al. lend support to this thesis, finding that households that had been issued contracts or certificates were significantly more likely to undertake investments than those that had not been issued contracts or certificates. ${ }^{140}$

While most empirical work has shown a strong linkage between tenure security and investment, some studies have found a rather limited connection between the degree of tenure security and investment. For example, Feder et al. find no statistically significant relationship between tenure security and investment in farm-related capital, with tenure security being measured by farmers' assessment of the probabilities of a) the re-allocation of land during the contractual period, and b) receiving the same plot of land when the contract is renewed. ${ }^{141}$ Interestingly, Feder et al. also find mixed results relating to access to credit. They find that in certain areas, where there are constraints on the availability of certain inputs, the lack of access to credit is not a significant constraint on investment. ${ }^{142}$ Where inputs to production are available, however, greater access to credit would increase farm investment. Similarly, Guo Li, in a 1999 unpublished $\mathrm{PhD}$ dissertation, provides a comprehensive overview of land rights

(2002) (supporting the assertion that increased tenure security increases the incentives for long-term investments).

138 Klaus Deininger \& Songqing Jin, The Impact of Property Rights on Households' Investment, Risk Coping, and Policy Preferences: Evidence from China, 51 ECON. DeV. \& CUltural CHANGE 851, 852 (2003).

139 Wei Hu, Household Land Tenure Reform in China: Its Impact on Farming Land Use and Agro-Environment, 14 LAND USE POL. 175, 179 (1997).

140 Keliang et al., supra note 114, at 812-13 tbls. 15-16.

141 Feder et al., supra note 133, at 22-23.

142 Id at 22. 
and their effects on investment in China in which he concludes that while tenure security does increase the use of inputs and production, the efficiency loss from less tenure security is not large. ${ }^{143}$

These results suggest generally that although there might be some efficiency loss from the lack of formal title, this efficiency loss is not too large. This in turn suggests that the investment incentives, which the formalists posit would arise from more secure formal title, are limited. The question then arises as to why there is already a strong degree of agricultural investment in China without formal title. As Clarke points out, and as acknowledged by many of the informalist scholars discussed above, it may be that predictability and expectations, rather than formal rights per se, are the most important determinants of investment and growth. ${ }^{144}$ He suggests that this explains the difference between Township and Village Enterprises (TVEs), which despite their lack of formal rights face limited risk of expropriation and have grown even more quickly than grain output, and the agricultural sector, where the risk of expropriation has historically been somewhat higher. ${ }^{145}$ This type of reasoning has parallels in the agricultural sector, as a key determinant of agricultural investment may not be formal rights, but rather farmers' perception of predictability and continued access to a given plot of land. Indeed, this same reasoning may explain the early growth in agricultural productivity despite somewhat unclear and insecure rights; despite unclear formal legal entitlements, there is evidence that a majority of farmers felt that their tenure was relatively secure.146 The above reasoning also suggests, however, that agricultural growth might have been even stronger if farmers had held even greater levels of tenure security.

143 Guo Li, The Economics of Land Tenure and Property Rights in China's Agricultural Sector (Mar. 1999) (unpublished Ph.D. dissertation, Stanford University) (on file with author).

144 Donald C. Clarke, Economic Development and the Rights Hypothesis: The China Problem, 51 AM. J. CoMP. L. 89, 97-100 (2003).

145 Id. at 100-07.

146 James Kai-sing Kung \& Shouying Lui, Farmers' Preferences Regarding Ownership and Land Tenure in Post-Mao China: Unexpected Evidence from Eight Counties, 38 CHINA J. 33, 50-51 (1997) (finding that, with the exception of two countires, 61.9 percent of farmers were confident their plots would not be redrawn prior to their contracts' expiration). 
This type of predictability is often attributed to the strong social norms, the importance of relationships (guanxi), and the corporatist ethic present in rural China. ${ }^{147}$ It may be that strong social relationships have operated as a substitute for the rule of law in China; thus, within close-knit communities, the ongoing relationships between villagers and the local government and among the villagers themselves might provide a sufficient basis for tenure security. Indeed, a significant level of social trust between the local government and villagers would be consistent with the observation that a significant number of villagers support occasional land redistributions.

While tenure security has been a major source of debate in Chinese land policy, the issue of the development of land markets has also attracted attention. Land markets continue to be rather underdeveloped, and many villages continue to prohibit land transfers, despite laws to the contrary. ${ }^{148}$ While some informalists have claimed that administrative reallocations of land are necessary to ensure equity, Deininger and Jin have shown how land rental markets are actually better than administrative solutions in terms of both efficiency and equity considerations. ${ }^{149}$ In another paper, Deininger and Jin also find that the ability to transfer land significantly increased long-term agricultural investment.150 In comparing market and administrative land allocation mechanisms, Carter and Yao find that equity concerns trump efficiency considerations in administrative allocation. This means that, over time, administrative reallocations could lead to significant inefficiencies in land use. ${ }^{151}$

147 PeERENBOOM, supra note 129 , at 470.

148 Krusekopf, supra note 117, at 305-07.

149 Klaus Deininger \& Songqing Jin, Land Rental Markets as an Alternative to Reallocation? Equity and Efficiency Considerations in the Chinese Land Tenure System (World Bank Policy Research, Working Paper No. 2930, 2002), available at http:/ / papers.ssrn.com/sol3/papers.cfm?abstract_id=636292.

150 Deininger \& Jin, supra note 138 , at 864, 877.

151 Michael Carter \& Yang Yao, Market Versus Administrative Reallocation of Land: An Econometric Analysis, in DeVelopmental Dilemmas: LAND ReFORM AND Institutional Change IN CHINA 151, 162-64 (Peter Ho ed., 2005). 


\subsubsection{Housing in Urban China}

The legal framework regulating urban housing in China has been in a state of considerable flux in recent years. ${ }^{152}$ While private housing predominated prior to 1949, the newly-established Communist government sought to gradually replace private housing with public housing. Thus, in 1957, the government introduced the danwei (work-unit) system, under which most housing was provided by individuals' work-units. ${ }^{153}$ Various levels of government also took steps over this period to bring much of the privately-owned housing into the public sphere. ${ }^{154}$ Thus, over this period, housing was generally conceived of as a welfare benefit provided by one's employer or the state rather than as a tradable commodity. Over time, this led to significant inefficiencies. As rents were nominal, there was virtually no private investment in housing, and the danwei system was not able to provide a sufficient amount of housing for urban dwellers. Over time, this led to drastic housing shortages; one government estimate found a shortage of one billion square meters of housing

152 This section can only provide a brief overview of Chinese urban land law and policy. For additional materials that discuss these issues in much greater depth, see Qingshu Xie et al., The Emergence of the Urban Land Market in China: Evolution, Structure, Constraints and Perspectives, 39 URB. STUD. 1375 (2002).

153 Yan Song et al., Housing Policy in the People's Republic of China: An Historical Review, in EMERGING LAND \& HOUSING MARKETS IN CHINA 163, 164-68 (Chengri Ding \& Yan Song eds., 2005).

154 Id.; see also Yingshun Zhao \& Steven C. Bourassa, China's Urban Housing Reform: Recent Achievements and New Inequities, 18 HOUSING STUD. 721, 728-29 (2003) (discussing the steps taken by the Jinin government to force private homeowners to effectively turn their land over to the state). While the work-unit and the state played increasingly dominant roles in housing allocation over this period, it would be incorrect to say that private housing completely disappeared. $I d$. at 725. However, as Wilhelm points out, China had no formal property law until 1986. Thus, while there was some type of arrangement which resembled private property during this period, it existed very much in a grey area of the law. Katherine Wilhelm, Rethinking Property Rights in Urban China, 9 UCLA J. INT'L L. \& FOREIGN AFF. 227, 239 (2004) (defining private property rights at the time as being governed by "customary norms as demonstrated by actual practice" rather than by law). 
in 1978.155 Moreover, because housing was tied to the work-unit, population and labor mobility was significantly constrained. ${ }^{156}$

The transition towards a more market-based economy that began in 1978 resulted in increased recognition and legal protection of private property rights in urban housing. This has not meant entirely abandoning non-price mechanisms of housing allocation, such as employer-provided housing or other administrative allocation mechanisms; by contrast, such mechanisms have continued to play a significant role in providing housing. 157 However, it has meant allowing the development of a private housing market through legal reforms designed to clarify and strengthen property rights. The major legislation enabling the development of a private land market was the 1988 Land Administration Law, which specified that use rights to state-owned land, such as urban land, could be allocated to individuals or units. ${ }^{158}$ A 1990 regulation set the lengths of these use rights and

155 Song et al., supra note 153, at 168-69. In addition to housing shortages, the administrative allocation of land led to significant distortions in land use more generally, including large amounts of unused land and an unnecessarily high proportion of industrial land. On this point, see Chengri Ding, Land Policy Reform in China: An Assessment and Prospects, 20 LAND UsE POL'y 109 (2003).

156 Song et al., supra note 153, at 168.

157 See Ya Ping Wang \& Alan Murie, Commercial Housing Development in Urban China, 36 URB. STUD. 1475, 1485-87 (1999) (emphasizing that there has been significant variation among regions and economic classes in terms of marketbased versus administrative allocations of land). For a detailed overview of this two-track system as well as resulting inefficiencies, see Anthony Gar-On Yeh, The Dual Land Market and Urban Development in China, in EMERGING LAND \& HousING MARKETS IN CHINA, supra note 153, at 163, 165-68. See also Xing Quan Zhang, Urban Land Reform in China, 14 LAND USE POL'y 187, 193-94 (1997) (offering additional overview on the two-track system); Youqin Huang \& William A. V. Clark, Housing Tenure Choice in Transitional China: A Multilevel Analysis, 39 URB. STUD. 7 (2002) (analyzing various institutional and socioeconomic causes of inequalities in the two-track system).

158 Land Administration Law (promulgated by the Standing Comm. Nat'1 People's Cong., June 25, 1986, revised Dec. 29, 1988) art. 7, LAWINFOCHINA (last visited Nov. 21, 2008) (P.R.C.). This Law was amended in 1998 and again in 2004. See Land Administration Law, 1998, supra note 113 (amending the Land Administration Law of the People's Republic of China, previously revised at the 11th Session of the Standing Committee of the Tenth National People's Congress on August 28, 2004). Since 1982, the Chinese Constitution has provided that land in cities is owned by the state. XIAN FA art. 10 (1982). Thus, only use rights, rather than the actual ownership of the land itself, are allocated to individuals under the Land Administration Law. 
also specified that these rights could in certain cases be transferred or mortgaged. 159

However, despite increased formal recognition of housing rights in urban areas, many of the same sources of tenure insecurity in rural farmland have similarly caused unsecure or unclear property rights in urban areas. For example, significant tenure insecurity - as well as the actual dislocation of millions of individuals - has resulted from the fact that, under Chinese law, there are very few barriers preventing the state from expropriating land for construction or redevelopment. 160 While the law requires compensation for such expropriations, the local authorities that determine the appropriate measure of compensation for expropriation have generally provided compensation that falls below the replacement cost of the property. 161 Moreover, even to the extent that individuals have legally-protected property rights, individuals have often had significant difficulties asserting those rights, as judges - who are typically financially beholden to local authorities - have been reluctant to challenge decisions of local governments. 162

The 2007 Property Law may rectify some of these problems and strengthen urban dwellers' property rights, as it significantly clarifies a variety of aspects of land use rights including, perhaps most importantly, the types of compensation that are owed to

159 Interim Regulations Concerning the Assignment and Transfer of the Right to the Use of the State-owned Land in the Urban Areas (promulgated by the State Council of the PRC, May 19, 1990, effective May 19, 1990) arts. 4, 12 LAWINFOCHINA (last visited Oct. 30, 2008) (P.R.C.). Later regulations further clarified the transferability of use rights. See Provisional Rules on Administration of Allocated Land Use Right (promulgated by the State Land Administration, Mar. 8, 1992, effective Mar. 8, 1992) LAwINFOCHINA (last visited Oct. 30, 2008) (P.R.C.). For a more detailed overview of provisions of the Land Administration Law as well as its problems and subsequent amendments, see William Valletta, The Land Administration Law of 1998 and Its Impact on Urban Development, in EMERGING LAND \& HOUSING MARKETS IN CHINA, supra note 153, at 59.

160 See generally Wilhelm, supra note 154 (detailing the process by which the state expropriates land from landowners). See also Land Administration Law, 1998, supra note 113, at art. 58; Urban Housing Demolition and Relocation Management Regulations (promulgated by the PRC State Council, June 6, 2001, effective Nov. 1, 2001) available at http://www.cecc.gov/pages/virtualAcad /index.phpd?showsingle=2335 (last visited Nov. 21, 2008) (P.R.C.).

161 See Wilhelm, supra note 154, at 249 (noting that local governments have wide discretion in determining compensation).

162 Id. at 236. 
those individuals whose property is requisitioned. ${ }^{163}$ However, it remains to be seen whether this law will meaningfully strengthen individuals' security of tenure, as it appears that the principal source of tenure insecurity is not the lack of legal rights but rather the unenforceability of those rights.

From an economic development perspective, the formalization of property rights measures appears to have had mixed success. On the one hand, the use rights created by the 1988 law and clarified by subsequent legislation and regulations have appeared to generate a significant real estate boom and spur housing development.164 However, because of remaining uncertainty in property rights, as well the significant role still played by administrative actors in allocating urban housing, significant distortions remain in the urban housing market, including both high vacancy rates as well as over-inflated housing prices. ${ }^{165}$

\subsubsection{The Growth of Chinese Businesses}

Since the gradual move towards marketization began in 1978, the growth of business in China has been dramatic. In the 1980s, private enterprise was still viewed with suspicion by the state, and the legal framework was exceptionally inhospitable to private enterprise. ${ }^{166}$ The primary source of business growth during this period was from organizations such as TVEs, which included aspects of both public and private ownership, with some growth also coming from household businesses and other cooperative forms. ${ }^{167}$ TVEs were the most important source of economic growth, and the Chinese state sought to encourage their development by providing them with favorable tax treatment and extending significant loans. ${ }^{168}$ In practice such organizations often

163 Property Law, supra note 115, art. 42.

164 Wilhelm, supra note 154, at 243-47; Xing Quan Zhang, Development of the Chinese Housing Market, in EMERGING LAND \& HOUSING MARKETS IN CHINA, supra note 153 , at $183,185-89$.

165 Zhang, supra note 164, at 189-94; see also Jieming Zhu, A Transitional Institution for the Emerging Land Market in Urban China, 42 URB. STUD. 1369 (2005) (discussing the evolution of property rights over state-owned urban land).

166 Vai Io Lo \& Xiaowen Tian, Property Rights, Productivity Gains and Economic Growth: The Chinese Experience, 14 POST-COMMUNIST ECONS. 245, 246-48 (2002).

167 Yanlai Wang, China's ECONOMic Development and Democratization 152-55 (2003).

168 Lo \& Tian, supra note 166 , at $246-47$. 
operated as private firms, but they formally maintained the structure of a TVE because of the accompanying benefits. 169

In 1988 private enterprises were provided with some degree of legal recognition and protection. The constitution was amended in April 1988 to permit the existence of the private sector and to guarantee its rights. 170 This was followed shortly thereafter by provisional regulations of private enterprises. These regulations formally provided some degree of protection for private businesses' property rights, specifying that private enterprises had the right to own and transfer property. ${ }^{171}$

These initial moves were followed by further legal protections in the 1990s. Forms of business organizations were clarified with enactments of the first Company Law in 1993 and the Partnership Law in 1997.172 This was followed in 1999 by a constitutional amendment that further strengthened the property rights of individuals and private enterprises. ${ }^{173}$ Over the period during which these changes were occurring, the private sector's share of industrial output grew dramatically from 8 percent in 1988 to 38 percent in 1998.174 Moreover, foreign investment in China has also increased dramatically since greater legal protections were implemented. ${ }^{175}$

Despite a more hospitable legal framework than was present in the 1980s, the protection of property rights has remained far from perfect for Chinese businesses for a number of reasons, many of

169 Id.

170 XIAN FA art. 11 (1988) (P.R.C.); WANG, supra note 167, at 156.

171 Lo \& Tian, supra note 166, at 249.

172 Id. See Company Law (promulgated by the Standing Comm. Nat'l People's Cong., Dec. 29, 1993, effective July 1, 1994) LAWINFOCHINA (last visited Nov. 21, 2008) (P.R.C.); Partnership Business Law (promulgated by the Standing Comm. Nat'l People's Cong., Feb. 23, 1997, effective Aug. 1, 1997) LAWINFOCHINA (last visited Oct. 30, 2008) (P.R.C.).

173 XIAN FA art. 11 (1999) (P.R.C.); Lo \& Tian, supra note 166, at 249.

174 Lo \& Tian, supra note 166, at 250. Despite this significant growth in private enterprise, state-owned enterprises continue to play a significant role in the Chinese economy. For an overview of the important role of state-owned enterprises in the Chinese economy as well as some of the problems of this arrangement, see Harry G. Broadman, The Business(es) of the Chinese State, 24 WORLD ECON. 849 (2001). For a paper exploring the superior economic performance of TVEs relative to state-owned enterprises, see Yusheng Peng, Chinese Villages and Townships as Industrial Corporations: Ownership, Governance, and Market Discipline, 106 AM. J. Soc. 1338 (2001).

175 PeERENBOOM, supra note 129, at 463-64. 
which have been noted above. Since local governments tend to be selective and self-interested in enforcing laws and regulations, the enforcement of laws and the effective degree of protection of property rights is much weaker than the legal framework would suggest. ${ }^{176}$ Moreover, the lack of an unbiased and effective judiciary has rendered many businesses unable to enforce their rights. ${ }^{177}$ Finally, the predatory tendencies of various levels of government have meant that businesses have been pressured or otherwise forced to give up their assets to the state.178 Thus, as Peerenboom concludes, "China's legal system undeniably still falls far short of any reasonable standards for rule of law," and there are still significant risks facing firms operating in China. ${ }^{179}$ The question that then arises is how such dramatic economic growth was possible without the security and clarity of formal property rights.

One explanation offered for such remarkable economic growth in the absence of strong formal property rights is the presence of relational networks and guanxi, which substitute for formal property rights regimes. For example, Weitzman and $\mathrm{Xu}$ argue that the economic success of TVEs is best explained by the high levels of trust among villagers in rural China, which allows villagers to successfully run cooperative firms despite exceptionally unclear property rights underlying such organizations. ${ }^{180}$ Consistent with the informalist literature discussed above, it may be that tight social networks and the repeated-game nature of villager participation in TVEs have allowed such organizations to flourish. However, while TVEs generally have experienced significant economic success, some authors have argued that economic performance would have been

176 David Wank, Producing Property Rights: Strategies, Networks, and Efficiency in Urban China's Nonstate Firms, in PROPERTY RigHTS AND ECONOMIC REFORM IN CHINA 248, 251 (Jean Oi \& Andrew Walder eds., 1999).

177 Id.; PEERENBOOM, supra note 129, at 463-64.

178 Wank, supra note 176.

179 PEERENBOOM, supra note 129 , at 464.

180 Martin L. Weitzman \& Chenggang Xu, Chinese Township-Village Enterprises as Vaguely Defined Cooperatives, 18 J. COMP. ECON. 121, 136-41 (1994). For a paper which fleshes out Weitzman \& Xu's analysis, see Xiaolin Pei, Township-Village Enterprises, Local Governments and Rural Communities: The Chinese Village as a Firm During Economic Transition, 4 ECON. TRANSITION 43 (1996). 
even stronger under better defined property rights, 181 thus suggesting that there may be limits to the economic growth possible under unclear property rights.

Corporatist relationships between firms and various levels of government and influential individuals have also played a key role in the growth of Chinese firms. ${ }^{182}$ Even prior to the formal legalization of private enterprises in 1988, quasi-private enterprises were created under the guise of collective or co-operative enterprises with local governments. ${ }^{183}$ Che and Qian argue that in the face of a predatory state, such linkages between firms and local government can be beneficial for both parties. By operating within the governmental framework, the firm has greater security from expropriation or seizure of its assets and profits, and costly revenue hiding will decrease. Similarly, the government benefits because such enterprises often make significant contributions to public goods such as the provision of infrastructure. 184 Similarly, in his examination of TVE's, Li asserts that where the regulatory environment is unclear and the government might try to block certain transactions, ambiguous property rights might actually be more efficient than private property rights. ${ }^{185} \mathrm{Li}$ argues that this is the case because firms can gain political influence and help with regulatory issues through fuzzy connections and a corporatist arrangement with the local government. The government, on the other hand, can use the TVE as a mechanism for achieving certain policy goals, such as curbing unemployment. ${ }^{186}$ This suggests that TVE's nebulous ownership structure may actually provide greater opportunities for growth than would strictly private firms.

The strength of informal relationships in China may also explain certain aspects of the finance and governance of private Chinese firms. For example, Allen, et al. note that publicly listed

181 See e.g., Chun Chang et al., Incentive Contracting Versus Ownership Reforms: Evidence From China's Township and Village Enterprises, 31 J. COMP. ECON. 414, 426 (2003) (concluding that "changing from collecting ownership to stock-based ownership can bring about significant efficiency gains during the transition period when market-supporting institutions are developing").

182 PEERENBOOM, supra note 129, at 430; WANK, supra note 176.

183 WANG, supra note 167, at 152-53.

184 Jiahua Che \& Yingyi Qian, Insecure Property Rights and Government Ownership of Firms, 113 Q. J. ECON. 467 (1998).

185 David D. Li, A Theory of Ambiguous Property Rights in Transition Economies: The Case of the Chinese Non-State Sector, 23 J. COMP. ECON. 1 (1996).

186 PEERENBOOM, supra note 129 , at 486-87. 
companies perform much worse than privately held companies. They explain the poor performance of the former through weak securities regulation and ineffective corporate governance, while they explain the stronger performance of the latter by citing strong personal relationships which allow companies to raise money easily through informal credit markets and which constrain opportunistic corporate governance. ${ }^{187}$ This explanation accords with the informalist literature examined above, as cooperative relationships are obviously easier to sustain in the tight-knit context of a family firm or small business than they are in the detached environment of public corporations. ${ }^{188}$ Similarly, some authors have argued that relational networks explain the significant amount of foreign direct investment which has flowed into China despite the absence of strong formal institutions. ${ }^{189}$

While guanxi and corporatist linkages may provide some degree of property protection in an insecure environment, they also have a number of drawbacks which may ultimately slow the growth of business. ${ }^{190}$ First, in some cases, otherwise inefficient firms may survive because of local government support, thereby straining government resources and allowing inefficient firms to survive. ${ }^{191}$ Second, the integration of businesses with political entities means that the success of a business may be more dependent on an individual's political connections than on the true profitability of the enterprise. ${ }^{192}$ Third, property protections based on such connections may present opportunities for corruption and rent-seeking. 193 Fourth, extensive reliance on such linkages may undermine efforts at promoting the rule of law in the long term.194

187 Franklin Allen et al., Law, Finance, and Economic Growth in China, 77 J. FIN. ECON. 57 (2005).

188 This position is also consistent with, though not identical to, Burkart, et al.'s argument that where protections for minority investors are weak, firms will be owned and managed by the same individuals; i.e. family firms will be the norm. See Mike Burkart et al., Family Firms, 58 J. FIN. 2167 (2003).

189 See e.g., Hongying Wang, Informal Institutions and Foreign Investment in China, 13 PAC. ReV. 525 (2000).

190 See generally MinXIN PeI, ChINA's TrapPED TRANSITION: THE Limits OF DEVELOPMENTAL AUTOCRACY 180-81 (2006) (warning that the lack of reform measures encourages, among other severe economic consequences, bad loans which threaten the country's entire financial sector).

191 PeERENBOOM, supra note 129, at 470-71.

192 Wank, supra note 176, at 262.

193 PeERENBOOM, supra note 129, at 472.

194 Id. 
Finally, personal relationships simply might not provide sufficiently strong protection of property rights in many cases. Thus, although corporatist arrangements can substitute for formal property rights to some extent, they can create substantial social costs which could be avoided by a strong formal property rights regime.

\subsection{The Costs of a Formal Property Rights Regime}

\subsubsection{Monetary Cost}

While the formalists may be correct about the efficiency gains which arise from formal property rights, some scholars contend that those efficiency gains may, in some circumstances, be outweighed by the costs of creating and enforcing the property rights regime. As Demsetz pointed out, the costs of creating and maintaining a formal property rights regime can outweigh the benefits arising from the regime, especially in cases where land is relatively abundant.195 Anderson and Hill similarly note that "[e]stablishing and protecting property rights is very much a productive activity toward which resources can be devoted. But, like any other activity, the amount of this investment will depend on the marginal benefits and costs to investors of allocating resources to these endeavors." 196

With respect to creating a formal regime, there are a variety of initial costs, including surveying land, creating a title registry, adjudicating conflicting claims, etc. As Banner points out, the transaction costs associated with valuing and allocating rights can be extremely high in the transition from one property rights regime to another. ${ }^{197}$ In a survey of various papers which attempt to quantify the direct costs of creating land registration systems, Hanstad notes that land registration has been in some cases as expensive as $\$ 240$ per parcel. 198 Moreover, there may be additional indirect costs in educating people about the benefits and mechanics

195 Demsetz, supra note 11, at 350-53.

196 Terry L. Anderson \& P.J. Hill, The Evolution of Property Rights: A Study of the American West, 18 J.L. \& ECON. 163, 165 (1975).

197 Stuart Banner, Transitions Between Property Regimes, 31 J. LEGAL STUD. 359, 364-65 (2002).

198 Hanstad, supra note 27, at 664-65. 
of titling, without which the informal system may continue to prevail.

Once the regime is created, there are ongoing costs required to maintain it. While land registries, either in the form of deed recording systems or title registries, ${ }^{199}$ provide the greatest degree of security and clarity, they also require continual updating and maintenance, thereby creating a number of ongoing costs. These costs can often outweigh the benefits supposedly derived from formal property rights.

The costs may also differ depending on the nature of the property in question. As Baland and Platteau note, the relative costs of maintaining and enforcing a property regime increase as the physical space which that resource occupies increases. ${ }^{200}$ This suggests that especially in areas where land is used extensively rather than intensively-such as grazing land for animals-the costs of enforcing private property rights may be high relative to the benefits.

\subsubsection{Social Insurance and Equity}

Where communal land has traditionally played a role as a collective insurance mechanism, the titling of that land might eliminate that mechanism while not replacing it with anything else. ${ }^{201}$ Richard Posner examines a number of insurance mechanisms in traditional societies and argues that traditional institutions, such as communal land or frequently redistributed land, can be efficient in some circumstances.202 Baland and Francois formally model the insurance function of communal land and show that where there exist incomplete insurance markets

199 Hanstad, supra note 27, at 650-51.

200 Jean-Marie Baland \& Jean-Philippe Platteau, Division of the Commons: A Partial Assessment of the New Institutional Economics of Land Rights, 80 AM. J. AGRIC. ECON. 644, 645 (1998).

201 Rohini Pande \& Christopher Udry, Institutions and Development: A View from Below 25-30 (Yale Univ. Econ. Growth Ctr., Discussion Paper No. 928, 1999), available at http://papers.ssrn.com/sol3/papers.cfm?abstract_id=864044; Michael J. Trebilcock, Communal Property Rights: The Papua New Guinean Experience, 34 U. TORONTO L.J. 377 (1984). For a discussion of some of the geographical conditions under which the communal property arrangements are efficient, see Jeffrey B. Nugent \& Nicolas Sanchez, Common Property Rights as an Endogenous Response to Risk, 80 AM. J. AGRIC. ECON. 651 (1998).

202 Richard Posner, A Theory of Primitive Society, with Special Reference to Law, 23 J.L. \& ECON. 1 (1980). 
because of either information asymmetries or limits on contract enforcement-two very plausible conditions in many developing countries-if individuals are sufficiently risk averse and the efficiency gains from privatization are sufficiently limited, privatization of communal land can be welfare-decreasing. ${ }^{203}$ By contrast, Platteau argues that population pressures will naturally lead to the erosion of this insurance function, 204 but he also acknowledges that the individualization of land tenure rights can be a separate force which leads to this outcome. ${ }^{205}$

Related to this problem is the emergence of a landless class, which is much less likely where land is redistributed.206 André and Platteau show how mounting population pressures and the development of informal land markets in Rwanda led to distress sales and the growth of a landless class. ${ }^{207}$

This issue has been studied in the Chinese context, where a body of literature suggests that some Chinese farmers actually seem to prefer periodic redistribution because of the social insurance function which such redistribution plays. For example, Kung and Liu claim that almost two-thirds of the farmers they surveyed were opposed to stable tenure in the form of thirty-year land contracts. ${ }^{208}$

Interestingly, Deininger and Jin have documented a type of learning effect, as households in an area which exogenously introduced greater tenure security were, ceteris paribus, generally more in favor of tenure security than those elsewhere.209 Kung examined the village of Meitan in Guizhou province, the same province that Deininger and Jin studied, and actually found a

203 Jean-Marie Baland \& Patrick Francois, Commons as Insurance and the Welfare Impact of Privatization, 89 J. PUB. ECON. 211 (2005); see also DEININGER, supra note 5, at 29-30 (arguing that local communities can provide some insurance value because unlike centralized bureaucracies, they have better access to private information). 78.

204 For a discussion of this point in Rwanda, see André \& Platteau, supra note

205 Jean-Philippe Platteau, The Gradual Erosion of the Social Security Function of Customary Land Tenure Arrangements in Lineage-Based Societies 26 (World Inst. for Dev. Econ. Res., Discussion Paper No. 2002/26, 2002), available at http://www.ciaonet.org/wps/plj01/plj01.pdf.

206 Platteau, supra note 22, at 65-69; Deininger \& Feder, supra note 18, at 2-3; Hanstad, supra note 27.

207 André \& Platteau, supra note 78, at 24-29.

208 Kung \& Liu, supra note 146, at 54.

209 Deininger \& Jin, supra note 138 , at 864. 
contrary result, finding that the introduction of more secure tenure had actually caused some in Meitan to oppose tenure security in favor of periodic reallocations. ${ }^{210}$ Not surprisingly, those who continued to favor tenure security were those that had benefited from it, i.e., older families who had previously been assigned large amounts of land.

\subsubsection{Undermining Informal Mechanisms of Tenure Security}

In undertaking a cost-benefit analysis of a formal property rights regime, it is important to take into account the effect that formalization has on informal norms. In certain situations, the institutionalization of new formal norms can damage or disrupt informal norms. A theoretical account of this is given by Pildes, who notes that state action can undermine norms through three broad processes: by destroying the social conditions that enable reciprocity; through direct attacks on the norms of reciprocity; and, with failures by the state to appreciate the broad context in which norms emerge.211 Similarly, Kahan shows how governmental incentive schemes can be seen as a social cue that individuals are not inclined to cooperate voluntarily, and legislation can actually weaken social norms. ${ }^{212}$

Applied to the context of property, these theories suggest that the formalization of title may potentially undermine norms of voluntary respect and cooperation for tenure security, thereby leading to less secure property rights. This is especially true if there are substantial transaction costs for the individuals seeking to enforce them. Moreover, as Lanjouw and Levy note, "if one takes an area with a long-standing and well-understood customary property rights system and overlays a formal state titling program, it can make residents less secure because they are unsure which system will apply in any given situation."213 For example, Besteman notes that customary land tenure in Somalia was quite

210 Kung, supra note 124, at 798 (noting that surveys indicated a three-fold increase-from 16 percent to 48 percent of those surveyed-in those preferring land reassignment to stable land tenure during this period).

211 Richard H. Pildes, The Destruction of Social Capital Through Law, 144 U. PA. L. REV. 2055, 2067-73 (1996).

212 Dan M. Kahan, The Logic of Reciprocity: Trust, Collective Action, and Law, 102 MicH. L. REV. 71, 76 (2003).

213 Jean O. Lanjouw \& Philip Levy, A Difficult Question in Deed: A Cost-Benefit Framework for Titling Programs, 45 WM. \& MARY L. REV. 889, 905 (2004). 
secure and that titling programs actually decreased security by calling into question the applicability of customary law and by creating the possibility of dispossession of unregistered farmers who continued to abide by customary law. ${ }^{214}$ There is also some evidence which suggests that land held under customary tenure may be less prone to land conflicts than land held under newer alternative forms of tenure, because the former is viewed as more legitimate than the latter. ${ }^{215}$ Cases have also been noted where the formalization of property rights has undermined traditional resource management arrangements. For example, Jodha has documented how changes in village governance structures in parts of India and the privatization of certain plots of land have undermined traditional arrangements for the efficient management of common property resources. ${ }^{216}$

A related problem in the property context is that the formalization of individual property rights may erode the rich and often disaggregated bundles of customary entitlements to land. As Banner notes, while in contemporary developed countries land is primarily allocated on a spatial basis, there have been, and continue to be, numerous property rights regimes where property rights are allocated on a functional basis.217 Because customary practices often provide different owners with different rights to the same land - such as the right to grow cash crops, the right to graze cattle, the right to gather firewood, the right to use streams on the land for water, the right to traverse, etc. - the creation of exclusive individual rights can undermine traditional activities which depended on this (by Ellickson's hypothesis, probably socially efficient) property rights division. ${ }^{218}$ Put differently, the transition

214 Catherine Besteman, Individualisation and the Assault on Customary Tenure in Africa: Title Registration Programmes and the Case of Somalia, 64 AFR.: J. INT'L AFR. INST. 484, at 498-99 (1994).

215 See Klaus Deininger \& Raffaella Castagnini, Incidence and Impact of Land Conflict in Uganda, 60 J. ECON. BEHAV. \& ORG. 321, 336 (2006) (discussing how the application of customary law in Uganda leads to less conflicts when compared to the newer formal titling system instituted by the 1998 Land Act).

216 N. S. Jodha, Depletion of Common Property Resources in India: Micro-level Evidence, 15 Population \& Dev. Rev. 261, 262 (1989); see also N. S. Jodha, Population Growth and Decline of Common Property Resources in Rajasthan, India, 11 POPULATION \& DEV. REV. 247 (1985).

217 Banner, supra note 197, at 365.

218 See Platteau, supra note 22, at 71-73 (discussing the importance of community based solutions in sub-Saharan Africa where property rights are divided on a use basis); see also María E. Fernández-Giménez, Spatial and Social 
from a functional to a spatial property system can entail significant costs and necessitate significant and potentially deleterious social reorganization. While it is possible, theoretically, to formalize a functional property system and disaggregate all the rights over a certain piece of land, this would almost certainly be prohibitively costly, both to record the various rights initially as well as to keep track of various changes over time. ${ }^{219}$

\subsubsection{Social Unrest}

There may also be externalities to the process of assigning property rights in the form of social conflict. 220 In addition to the possibility of conflict caused by the perceived illegitimacy of a new tenure system, there are two additional mechanisms through which formalizing land tenure can lead to social conflict. First, proponents of titling and registration programs often implicitly assume that boundaries between property rights are clearly defined. However, if such boundaries are undefined or fuzzy, titling programs can cause conflicting claims to the rights to surface.221 Two attempts by the Australian government to formalize land rights in Papua New Guinea created new land disputes, as individuals were concerned about losing customary entitlements and the accompanying finality of land holdings that resulted from the registration process.222 Returning to the Chinese case study, Ho argues that China has deliberately maintained a degree of legal ambiguity in its property rights arrangements in order to minimize conflict between groups and to allow for further

Boundaries and the Paradox of Pastoral Land Tenure: A Case Study from Postsocialist Mongolia, 30 Hum. ECOLOGY 49, 50 (2002) (discussing how the spatial allocation of land in Mongolia is difficult because "spatial and social flexibility are intrinsic and essential characteristics of resource use patterns").

219 See Platteau, supra note 22, at 58 (noting that disaggregating use rights would be prohibitively costly in countries such as Zambia and Rwanda).

220 See Daniel Fitzpatrick, Evolution and Chaos in Property Rights Systems: The Third World Tragedy of Contested Access, 115 YALE L.J. 996, 1009 (2006) (noting that those such as Demsetz and Coase who push for property rights as a way to internalize externalities "overlook the possibility that the allocation process will create its own externalities in the form of social conflict").

221 See Hanstad, supra note 27, at 666 (nothing that formalization of title when significant fragmented holdings existed created significant problems for Sicilian and Chinese landowners).

222 Trebilcock, supra note 201, at 413 (noting that the very act of embarking on land registration precipitated disputes due to the "once and for all" nature of land registration). 
development of property institutions in the future.223 Whether or not this has actually limited conflict is unclear, as land disputes have become increasingly frequent in rural China. ${ }^{224}$

Second, where titling programs transfer title from absentee landholders to occupants instead of simply titling untitled state land, a relatively simple formalization program can encourage invasions by squatters. In their study of land reform in the Brazilian rainforest, Alston et al. found that a government program designed to expropriate unused land from large landowners and transfer it to peasants actually increased land conflict by encouraging peasants to invade and squat on land and assert claims to this land under the principles of the government's redistributive land policies.225 Thus, while a strong formal property rights regime can prevent conflict and wasteful competition for resources once such a regime is successfully instituted, the process of creating and formalizing such a regime can itself lead to significant conflict, at least in the short term.

\subsubsection{The Flaws of a Titling Process}

In other circumstances, the titling process itself can be carried out in such a way as to further marginalize already disenfranchised groups.226 Two such groups have been the focus of substantial study. First, titling programs which destroy customary tenure can significantly erode women's rights. This can occur for a number of reasons. The titling process will often provide title to land solely to men, while women will lose their customary rights. ${ }^{227}$ Lastarria-

223 Ho, supra note 112 , at 73.

224 See PEERENBOOM, supra note 129, at 482-83 (discussing a recent land survey where many farmers felt insecurity in their tenure over their land).

225 Lee J. Alston et al., A Model of Rural Conflict: Violence and Land Reform Policy in Brazil, 4 ENV'T \& DEV. ECON. 135, 136 (1999).

226 See generally Jean-Philippe Platteau, The Evolutionary Theory of Land Rights as Applied to Sub-Saharan Africa: A Critical Assessment, 27 DEV. \& CHANGE 29, 39-46 (1996) (arguing that land registration increases certainty but tends to deprive access to marginalized groups, reducing efficiency and security, and is feared to be manipulatable by the elite and educated to their advantage).

227 See Besteman, supra note 214, at 495 (noting that once formal titling was instituted in Somalia, the cultural rights that women were once guaranteed under the Sharia were largely ignored); Carmen Diana Deere \& Magdalena León, Who Owns the Land? Gender and Land-Titling Programmes in Latin America, 1 J. AGRARIAN CHANGE 440, 443 (2001) (noting that the most successful programs were those which came from nations such as Colombia, Honduras, and Nicaragua where women's rights are independently protected); Susana Lastarria-Cornhiel, Impact of 
Cornheil notes that the move to a market for land may disenfranchise women as the market may not be gender-neutral. She points out that not only are there often institutionalized male biases against women owning land, but women also enter the market at a disadvantage due to their lack of cash or access to credit, lack of political power, and the fact that they have a family to maintain.228 Finally, the transition from a functional to a spatial property regime, as discussed above, can be particularly devastating for women, whose livelihood often depends significantly on certain limited use rights, such as rights to collect wood and access to grazing land. ${ }^{229}$ However, whether titling programs strengthen or weaken women's rights depends on the implementation of the titling program as well as the strength of supporting institutions for women's rights. Where legal protections are otherwise strong for women, programs such as joint titling may actually strengthen their position relative to customary law. ${ }^{230}$

The empirical evidence assessing the impact of titling programs on women's rights is somewhat mixed. While in some cases titling has eroded women's customary rights, this has largely depended on how the titling program was carried out. Deere and Leon's study is illustrative. They provide an overview of four different titling programs in Latin America and find mixed results, largely varying on how the program was executed and to what extent the program provided adequate legal protections for women rather than on the effect of titling itself. ${ }^{231}$ Gopal provides an account of

Privatization on Gender and Property Rights in Africa, 25 WORLD DEV. 1317, 1320 (1997) (explaining how colonial lands switched from traditional tenure ownership in pre-colonial Africa with a greater variety of gender patterns, to personal property held by the head of the household).

228 Lastarria-Cornhiel, supra note 227, at 1326-27.

229 See Thea Hilhorst, Women's Land Rights: Current Developments in SubSaharan Africa, in Evolving LAND RigHTS, POLICY AND TENURE IN AFrICA 181, 185 (Camilla Toulmin \& Julian Quan, eds., 2000) (describing the characteristics of female employment working the land, including their lack of incentives to develop the land, and what factors influence the extent of their agriculture activities).

230 See Aili Mari Tripp, Women's Movements, Customary Law, and Land Rights in Africa: The Case of Uganda, 7 AFR. STUD. Q. 1, 11 (2004) (describing the push/pull effects of legal land rights and community-oriented ideals).

231 Deere \& Leon, supra note 227, at 443 (discussing how the implementation of formal titling programs in several Latin American countries has significantly undercut many women's rights to land). 
the impact of land reform on women in Kenya and Ethiopia and finds similarly mixed results. ${ }^{232}$ In Kenya, she finds that land tenure reform damaged women's customary usufructury rights by not providing any adequate safeguards, thereby turning them into an "agrarian proletariat." 233 In Ethiopia, the land reform program was somewhat more successful, although by 1996, still only 18 percent of landowners were female. ${ }^{234}$ Firmin-Sellers and Sellers, however, come to a more pessimistic conclusion in their study of Cameroon. They note that while customary rights granted women ownership over food crops and men ownership rights over tree crops, the titling process has tended to marginalize women's claims as titles over the property were almost entirely granted to men. 235

Second, even in circumstances where the titling process would provide substantial benefits along the lines discussed by the formalists, differential access to formal titling because of differences in education, wealth, or political power can create inequitable results and actually dispossess individuals of their land.236 Even where registration is theoretically equally accessible to all, rural landowners may be misinformed and not fully understand the benefits of registration; conversely, elites may be able to manipulate the system and claim rights over large portions of land. Moreover, in cases where there is any charge for titlingor even when there are large indirect costs for registration, such as the requirement to travel a significant distance to the capital to register the land-wealthy elites will be significantly better positioned than the poor to reap the benefits from titling programs.

There is indeed evidence that titling programs have in some cases disproportionately benefited the elites of a given society at the expense of the poor. Feder and Noronha cite a number of studies indicating that it was chiefs and civil servants who had superior knowledge of the law that benefited from land

232 Gita Gopal, World BANK, GENDER-RELATED LEGAl REFORM AND ACCESS TO ECONOMIC RESOURCES IN EASTERN AFRICA 2-3 (1999).

233 Id. at $12-13$.

234 Id. at 13.

235 Kathryn Firmin-Sellers \& Patrick Sellers, Expected Failures and Unexpected Successes of Land Titling in Africa, 27 WORLD DEV. 1115, 1119 (1999).

236 See Platteau, supra note 22, at 67-68 (discussing how the high level of wealth concentration in new formal title systems has led to a further concentration of wealth). 
registration in Kenya. ${ }^{237}$ Similar manipulation was documented by Doornbos in Uganda's titling program. ${ }^{238}$ However, it should be noted that, as with the discussion of the impact of titling on women's rights, it is not titling itself which necessarily leads to this deleterious effect, but rather the manner in which it is carried out. While titling programs need not lead to the further marginalization of already marginalized groups, the impact of such programs on those groups cannot be ignored, as improperly designed programs can have deleterious consequences.

\subsection{Concluding Remarks on the Costs and Benefits of a Formal Property Rights Regime}

The above discussion of the costs and benefits of a formal property rights regime suggests that the picture is much more complex than many commentators and policy-makers have assumed. The creation of a formal property rights regime is not costless, and it will not necessarily be the case that the benefits of such a regime will clearly outweigh the costs. Given, however, that formal property regimes are ubiquitous in the developed world, there are reasons to believe that at a certain stage in a country's economic development, a formal property rights regime is necessary to secure further economic development. 239

At low levels of development, an informal regime may be adequate to realize many of the benefits of private property. Where economic life is largely organized around small units such as the village, the mobility of the population is low, and resources such as land are not overly scarce, informal mechanisms will likely be sufficient to provide the benefits of private property. Put differently, if individuals expect to be living in the same location, expectations of repeated interactions will create the conditions necessary for cooperation. At this point, informal mechanisms will likely suffice to bring the benefits of private property, so a formal

237 Feder \& Noronha, supra note 58, at 156-57.

238 Martin R. Doornbos, Land Tenure and Political Conflict in Ankole, Uganda, 12 J. DEV. STUD. 54, 63 (1975).

239 Indeed, this view seems consistent with China's experience over the last three decades. As discussed above, supra Section 2.1.5, China experienced rapid growth throughout the 1980's without clear property rights. However, as economic development has progressed, China has increasingly tried to create a functioning formal property rights system. 
property regime would entail significant social and economic costs without significant benefits.

As countries undergo economic changes, however, the relative benefits of a formal private property regime are likely to increase. There are three general reasons for this consequence. First, as development increases, communities are likely to become less close-knit, leading informal norms to be less effective in maintaining order. As Feder and Feeny note, " $[\mathrm{w}]$ ith more advanced stages of development and increased mobility of individuals and entrepreneurs, transactions among individuals who are not members of the same community are more frequent." 240 Where the proportion of one-off encounters increases relative to continuing encounters, traditional methods of social cohesion are likely to be strained. Moreover, as Posner notes, while informal norms can often result in a strong degree of security for items which can be easily possessed, such norms will be inadequate to protect goods which individuals cannot directly possess, such as land or capital dispersed throughout a number of locations. ${ }^{241}$

Second, at higher levels of economic development, the value of land, goods, and investments may increase substantially, leading to more substantial benefits from more secure property rights. While informal mechanisms may be sufficient to provide an individual with the incentives to make minor investments, more capital-intensive, asset-specific investments will likely require greater certainty and security. Moreover, as the activities become increasingly capital-intensive, formal credit is likely to play a greater role in economic development, thereby increasing the benefits of clear and secure title.

Third, at higher levels of economic development, the relative costs of creating a formal property regime may be lower. As a country's tax base increases, it will be relatively easier for the state to make the expenditures required for creating a formal property regime. Where insurance markets are likely to be more developed, the loss of the insurance function of customary land tenure is likely to be less severe. Similarly, where the state takes an increasingly large role in providing social benefits to its population, the equity

240 Feder \& Feeny, supra note 17, at 140.

241 POSNER, LAW AND SOCIAL NORMS, supra note 56, at 178-79 (illustrating how "state intervention has raised welfare beyond the level produced by the evolution of norms" using possession-based resources as an example). 
concerns of potential landlessness are likely to be mitigated. Finally, the very forces that undermine informal tenure can also mitigate the effects of increased landlessness and social unrest. As mobility and migration opportunities increase, individuals will be more able to seek alternative economic opportunities elsewhere, thus lowering the cost to individuals of changes to property arrangements.

The above considerations suggest that the focus of certain previous titling programs may have been misguided both in terms of the targets of these titling programs as well as in the content of the formalization program. First, while many titling programs have focused on providing formal title to agricultural landowners, the above discussion suggests that, with the exception of newlysettled frontier land, established social norms in rural areas may be sufficient to provide an adequate degree of informal property rights protection. Urban titling programs, especially those aimed at newly-developing squatter settlements, may yield a greater social return. The greatest return from titling programs may come, however, from providing formal ownership to firms' land and assets, as informal norms may be lacking in such circumstances or inadequate to provide the certainty required for large investments or transactions entailing significant sunk costs and long pay-off periods. Second, to the extent that there are substantial benefits to providing stronger land rights to agricultural landowners in a given case, those benefits may be largely realized through the recognition and formalization of customary land tenure.242 This model of formalization in the agricultural sector may bring about the benefits of security of tenure at a lower social cost than would the de novo creation of an individual-centered system of land rights. Both of these conclusions, however, should be taken only as general propositions, as the above discussion highlights how the analysis of relative costs and benefits of formalization is a highly context-dependent exercise.

242 For an insightful exploration of many of these issues of institutional design, see Daniel Fitzpatrick, 'Best Practice' Options for the Legal Recognition of Customary Tenure, 36 DEV. \& CHANGE 449 (2005), which argues that conventional law-and-economics theory fails to explain the development of open access in many Third World property systems and that rising resource values are more likely to lead to open access than private property when the institutional environment is characterized by competing legal and norm-based systems. See generally DEININGER, supra note 5, at 62-65 (describing situations when eliminating or replacing customary tenure is neither necessary nor desirable). 
Finally, it should be noted that while the above discussion has largely focused on titling, the examples show that in some cases the primary source of insecure property rights is not the threat of expropriation by other households or landowners, but rather from expropriation by the state. ${ }^{243}$ Where this is the main source of insecurity, formal title per se may not be necessary to increase individuals' perceptions of tenure security. Moreover, under such circumstances, formal title may not actually improve perceptions of tenure security, if individuals believe that they will not be able to enforce their property rights against a predatory state. ${ }^{244}$ Rather, what is required in such cases to create the perception of strong property rights is a credible commitment by the state not to expropriate land or other assets. ${ }^{245}$ This can be a significantly less costly and more effective mechanism for gaining the benefits of private property rights than formal titling programs.

\section{THE PRECONDITIONS FOR A FORMAL PROPERTY RIGHTS REGIME}

A property rights regime does not exist in a vacuum, but rather its operation depends on its interactions with a number of related social institutions. This Section will examine the social, market, and state institutions which are conducive to or necessary for the operation of a formal property rights regime. Stated most generally, this Section will note that people may ignore the formal legal mechanisms and continue to adhere to informal norms if they find the latter to be more efficient and cost effective. ${ }^{246}$ A basic

243 See Timothy Frye, Credible Commitment and Property Rights: Evidence from Russia, 98 AM. POL. SCI. REV. 453, 456-458 (2004) (noting that one of the largest threats to property rights in Russia was a fear that the state would expropriate private property); see also Razzaz, supra note 104 (discussing the Bani-Hassan tribe's fear of expropriation from the Jordanian government). Various levels of government have been significant sources of property rights insecurity in China; for examples see supra text accompanying notes 122-24, 177.

244 See Frye, supra note 243, at 457-58 (describing a survey of Russian businessmen finding that many believe that they will not be able to enforce their property rights against the state).

245 See FuRUbotn \& Richter, supra note 12, at 97-100 (discussing the implications of state ownership of land and farmers' incentives to work).

246 See ElLICKSON, ORDER WithOUT LAW, supra note 51, at 15-28 (commenting on the irrelevance of formal law to the Shasta county ranchers); see also DE SOTO, supra note 7, at 154 (noting that in Peru extralegal entrepreneurs continue to work because it is more cost effective than actually complying with regulations); Feder \& Noronha, supra note 58, at 163 (concluding that in certain circumstances societies that are not ready for formal titling should remain with communal systems so long as it is more cost effective); Pande \& Udry, supra note 201, at 14 
point made by many authors - and stressed by De Soto - is that individuals will be more likely to continue to operate in the informal sector as the relative cost of operating in the formal sector increases. ${ }^{247}$

\subsection{Informal Norms}

Because the state can neither perfectly enforce all of its laws nor can citizens turn to the state for complete enforcement of their rights, the success and effectiveness of a formal legal system depends heavily upon the relationship between law and social norms. Law and social norms can in some circumstances be complementary. This is particularly the case when the law formalizes generally accepted practices. ${ }^{248}$ This does not necessarily imply legal or normative stagnation; incremental or marginal deviations in the law from social norms can play a role in gradually modifying those norms, thereby suggesting a potential path for reform. ${ }^{249}$ Some authors have noted the existence of legal obedience norms. ${ }^{250}$ If individuals have internalized such a norm, then they may use the formal legal system, if the costs of doing so-either the transaction costs or the inherent disutility of breaching other norms - are sufficiently low. Thus, whether legal reforms will be rendered less effective by social norms largely depends on how closely those legal reforms mirror social norms.

The linkages between law and social norms may explain some of the successes of Papua New Guinea's land courts-which in

(stating that adherence to customary land rights in sub-Saharan Africa is done so because it is more cost efficient to enforce as opposed to formal legal rights).

247 DE SOTO, supra note 7, at 154-55 (discussing how the only real method of effective enforcement against black markets is to make it prohibitively costly for merchants to operate); see also ELLICKSON, ORDER WITHOUT LAW, supra note 51, at 105 (discussing how Shasta county rangers will not comply with closed-range ordinances so long as it is not cost effective to do so).

248 See McAdams \& Rasmusen, supra note 43, at 4 (stating that legal norms and "real" norms are in less conflict when one is derived from the other).

249 See Dan M. Kahan, Gentle Nudges vs. Hard Shoves: Solving the Sticky Norms Problem, 67 U. CHI. L. REV. 607, 622-40 (2000) (discussing several instances, such as the change in drug laws, where norm reformers have been able to change the law by giving a "gentle nudge" in enforcement which ultimately led to a complete change in the law).

250 See McAdams \& Rasmusen, supra note 43, at 17 (describing the concept of legal obedience norms as "an obligation to act in according with the law"); see also Kahan, supra note 249, at 607 (discussing the reluctance of decisionmakers to implement a law that alters a social norm). 
some sense formalized customary title by preserving the customary rules for dealing with land 251 -as well as the corresponding failure of the conversion process to freehold in that country. $^{252}$ A related example from Cameroon also lends some support to this point. In many ways, the titling process in Cameroon was largely ineffective, with most farmers choosing to remain outside the legal system. However, by the process established in Cameroon, once farmers began the title process and paid certain fees, state agents would come to place concrete boundary markers on their land; following this, many farmers would give up on the formalization process. As Firmin-Sellers and Sellers note, while these boundary markers had no legal significance on their own, these markers enhanced tenure security because community members would believe that the land was in some sense backed by the state. This state action actually enhanced tenure security, since it a) was a relatively low-cost signal of tenure security, and b) did not conflict substantially with customary law as it existed in Cameroon. 253

By contrast, there may be informal norms that militate against the use of a more effective formal legal system. Kahan has noted that if norms conflict with the formal law, this may inhibit law enforcers from applying the formal law. ${ }^{254}$ Even beyond the law enforcers, if the formal law is in stark contrast with the norms of the individuals who are party to a dispute, they may simply avoid using it. Most pessimistically, in some circumstances there may be norms against using the formal legal system and instead in favor of resolving disputes informally.255 In these circumstances,

251 See Robert D. Cooter, Inventing Market Property: The Land Courts of Papua New Guinea, 25 LAW \& SOC'y REv. 759, 766-81 (1991) (describing customary rules for dealing with land in Papua New Guinea).

252 Robert D. Cooter, The Rule of State Law Versus the Rule-of-Law State: Economic Analysis of the Legal Foundations of Development 38-40 (John M. Olin Working Papers in Law, Econ., and Inst. No. 96/97-3, 1996) (discussing the failure of conversion to freehold in Papua New Guinea); see also Trebilcock, supra note 201, at 384-86 (discussing the aborted attempts to introduce registration systems in Papua New Guinea).

253 See Firmin-Sellers \& Sellers, supra note 235 (arguing that policy makers could redesign land tenure to give the state a more positive role).

254 Kahan, supra note 249 , at 607.

255 See Rikke J. Broegaard, Land Tenure Insecurity and Inequality in Nicaragua, 36 DEV. \& CHANGE 845, 845 (2005) (discussing the "lack of enforcement" and "lack of impartiality" in the formal systems of Nicaragua); see also ELLICKSON, ORDER 
individuals may be disinclined to make use of what might be a more efficient formal system.

Applied to the context of property, this may suggest that some of the benefits which the formalists suggest will arise from land titling programs may not materialize because of the social context. For example, the ability to use land as collateral requires the ability of creditors to seize the land. If, however, judges are unwilling to order that the land of a defaulting debtor be transferred to a creditor, or if creditors are for some other reason unable to effectively repossess the land because of local norms, the mere fact of titling will not enhance the ability of landowners to gain access to credit.

Norms can also play in important role in encouraging or discouraging the evolution of the institutions necessary for the benefits from private property to be realized. For example, Platteau has discussed how land markets will not develop as long as landowners feel, because of their own conceptions or because of social pressures, that their land is inalienable. ${ }^{256}$ Moreover, as Fitzpatrick points out, where common property arrangements are supported by and closely bound up with kinship structures, they may be exceptionally persistent in the face of external attempts to create a new property rights framework. ${ }^{257}$ Unsurprisingly, these considerations all suggest that one of the major determinants of a given formal property regime's acceptance and success will be its compatibility with informal norms and customs.

\subsection{The Existence of Other Markets}

The mere fact that individuals have some manner of formal individual property rights will not necessarily lead them to the neo-classical profit maximizing outcome, at least as long as supporting markets are undeveloped. ${ }^{258}$ Imperfections in credit,

WITHOUT LAW, supra note 51, at 123-36 (demonstrating how people often resolve their disputes in a cooperative fashion, without regard to formal legal systems).

256 Platteau, supra note 22, at 56-57.

257 See Fitzpatrick, supra note 220, at 1011-16 (discussing the importance of kinship networks in Third World societies).

258 See Christopher Udry, Efficiency and Market Structure: Testing for Profit Maximization in African Agriculture (June 1996) (unpublished working paper, on file with Northwestern University Department of Economics) available at http://www.econ.yale.edu/ cru2//pdf/separate.pdf (discussing the extent to which rural development is characterized by competitive markets). 
land, and labor markets can diminish the relative benefits of formal private property rights.

The existence of a well-functioning credit market is essential for many of the benefits of private property to be realized. Although the economic theory discussed above suggests that the potential collateral created by titling programs will increase the supply of credit, formal title will not increase farmers' access to credit if rural credit markets are themselves underdeveloped or imperfect. ${ }^{259}$ This will most obviously be the case where there are either formal restrictions which impede the efficient development of credit markets or where creditors are unable to use the legal machinery of the state to enforce debtors' obligations. ${ }^{260}$ Even absent such glaring failures, however, the transaction costs associated with lending may ration borrowers out of the credit market.261 Carter formally demonstrates how credit rationing can deprive smaller landholders of access to credit even in unrestricted credit markets because of adverse incentive and selection effects. ${ }^{262}$ There is some evidence suggesting that such credit rationing has occurred in practice. Field and Torero examine the impact of a titling program in Peru, and they find that 34 percent of titled households remain rationed out of the credit market.263 Boucher et al. find similar evidence of small farmers being rationed out of the credit market in Honduras and Nicaragua. ${ }^{264}$ Such credit-rationing also explains the results of Carter and Olinto. ${ }^{265}$

Such credit market inefficiencies can lessen the benefits of private property in a number of ways. First, the potential supply of agricultural improvements is reduced, as smaller farmers are unable to acquire the requisite capital to make efficient

259 See Migot-Adholla et al., supra note 76, at 166 (arguing that land titles alone will not lead to the development of active rural credit markets); see generally Boucher et al., supra note 23, at 109-10 (discussing "market-friendly" reforms in Honduras and Nicaragua).

260 On the second point, see Platteau, supra note 22, at 59-60.

261 See Deininger \& Feder, supra note 18, at 11 (suggesting that there are informal procedures with fewer transaction costs).

262 Michael Carter, Equilibrium Credit Rationing of Small Farm Agriculture, $28 \mathrm{~J}$. DEV. ECON. 83 (1988).

263 Field \& Torero, supra note 83 , at 16.

264 See Boucher et al., supra note 23, 109-10 (discussing ongoing credit constraints for small farmers).

265 See Carter \& Olinto, supra note 89 (arguing that "the credit supply effect tends to favor large-scale producers). 
improvements to their land. Second, where credit markets are limited and the purchase of land cannot be effectively financed, land will not necessarily be transferred to the most efficient producers. ${ }^{266}$ Third, as Boucher et al. argue, the differential availability of credit can actual harm labor opportunities for poorer farmers, at least in the short-term. This can occur because increased access to credit might allow large landowners to substitute away from labor in favor of capital-intensive farming, thus reducing the labor demand of large farmers.267 If this is coupled with newly titled landowners alienating their land to large landowners, ${ }^{268}$ the demand for rural labor might decrease substantially, with potentially negative socioeconomic consequences.

The underdevelopment of land markets can also negate some of the benefits of more formalized private property rights. Although many scholars assume that the formalization of property rights will facilitate the operation of land markets, in certain cases, because of the failures of other markets or the existence of certain social norms, the land market may be highly underdeveloped. Where there is not an active market in land, the other benefits of strong private property rights may be lessened. For example, if land markets are thin, land will be a highly illiquid form of collateral, thereby making it difficult for banks to foreclose mortgages; this will then hinder the ability of landowners to use their land as collateral to access credit markets. ${ }^{269}$ Moreover, if land is effectively inalienable, the value of improvements to land cannot be realized, thereby removing one of the avenues by which stronger property rights can increase investment.

Further inefficiencies can occur if there are simultaneous imperfections in both land and labor markets. Significant transaction costs in the labor market due to high search costs for labor or pronounced principal-agent problems can prevent households from employing an optimal amount of labor on their

266 For the theoretical discussion and a survey of applicable literature, see Deininger \& Feder, supra note 18.

267 See Boucher et al., supra note 23, at 110 (arguing that capital-intensive farming methods might reduce labor opportunities).

268 See text accompanying notes 206-207 (discussing problems of a landless class).

269 Irving Gershenberg, Customary Land Tenure as a Constraint on Agricultural Development: A Re-Evaluation, 4 E. AFr. J. RuRAL DeV. 51 (1971); Barrows \& Roth, supra note 77, at 295. 
plots, leading smaller households to be relatively less productive. ${ }^{270}$ Such labor market imperfections are less important if land rental or sales markets can transfer the use of that land from less efficient to more efficient producers. However, in the presence of imperfections in both labor and land markets, formal property rights will not be sufficient to lead to efficient uses of land.

\subsection{An Effective State}

A formal property rights regime cannot simply be created by decree; rather, it requires the state to create and maintain a variety of institutions. The most obvious set of necessary institutions are those which are directly responsible for the functioning of such a regime. These include an effective method of recording claims such as surveys and a title registry which can issue title and record changes reasonably quickly, reliably, and inexpensively.

Because these are often extremely complex systems, many states which have attempted to create such institutions and issue titles have been unsuccessful because of the significant inefficiencies in these systems. An important related case study describes Kenya's titling experience. ${ }^{271}$ There, the formal titling program begun in the 1950s was largely ignored. Unregistered land transfers through informal procedures occurred frequently, leading to increased insecurity and litigation. ${ }^{272}$ Also problematic was the fact that people often entirely ignored deeds; ownership of land was determined by pre-existing informal networks. Similarly, Firmin-Sellers and Sellers note that the formal titling program is Cameroon was irrelevant to most rural inhabitants, largely because of the exceptionally high costs - in the form of exceptionally long waits for title, corruption, etc. - of obtaining title.273 In

270 See Holden et al., Market Imperfections and Land Productivity in the Ethiopian Highlands 30-32 (International Food Policy Research Institute, Working Paper No. 76, 2001) available at http://www.ifpri.org/divs/eptd/dp/papers/eptdp76.pdf (describing market imperfections in rural African economies). For evidence and further discussion of labor market imperfections, see Udry, supra note 258.

271 Simon F.R. Coldham, Land-Tenure Reform in Kenya: The Limits of Law, $17 \mathrm{~J}$. Mod. AfR. StUd. 615 (1979); see also Angelique Haugerud, Land Tenure and Agrarian Change in Kenya, 59 AFR.: J. INT'L AFR. INST. 61 (1989) (describing Kenya's titling experience).

272 The opposite manifestation of this trend was apparent in Rwanda, where informal land markets developed because of the rapidly increasing value of land, despite the fact that such markets were illegal under Rwandan law. André \& Platteau, supra note 78 , at 1.

273 Firmin-Sellers \& Sellers, supra note 235, at 118-20. 
Madagascar, high costs associated with recording land transactions meant that the title registry became increasingly out of date over time; property was largely defined by informal documents noting land transfer and ownership status. ${ }^{274}$ In urban Vietnam, relatively few residents have taken advantage of titling programs because of the strict requirements for documentary evidence needed to prove residence as well as the fees involved in acquiring title. ${ }^{275}$

In their study of the land registry program in St. Lucia, Barnes and Griffith-Charles come to a related but slightly different conclusion. As with the above studies, they find that over time the formal property system is becoming increasingly irrelevant, as transfers in ownership fail to be recorded in the national registry. ${ }^{276}$ Unsurprisingly, this is linked to the cost of recording such changes. Surprisingly, however, they find that landowners systematically overestimate the costs of formally recording land transfers. ${ }^{277}$ This indicates that even where actual costs of formalization are low, the higher perceived costs of formalization may dissuade individuals from using the formal system.

While a successful formal property rights regime requires the creation of a number of specialized property-related institutions, it also requires the existence of a number of related state institutions that are necessary for the maintenance of the rule of law. Without the existence of institutions, which allow property owners to enforce their rights, those rights are meaningless, and the formal regime will not bring the benefits which it is supposed to provide. Under these circumstances, individuals will continue to rely on informal mechanisms for securing their rights, which, as discussed above, can significantly limit economic development beyond an undetermined point. ${ }^{278}$

274 Jacoby \& Minten, supra note 79, at 465-69.

275 See Kim, supra note 80, at 281-86 (discussing the documentation and enforcement of property rights in Vietnam, specifically contrasting title and legal papers).

276 See Grenville Barnes \& Charisse Griffith-Charles, Assessing the Formal Land Market and Deformalization of Property in St. Lucia, 24 LAND UsE POL. 494, 500 (2007) (finding that land titling and registration are not sufficient to create and maintain a formal land market).

277 Id. at 499.

278 See Richard E. Messick, Judicial Reform and Economic Development: A Survey of the Issues, 14 WORLD BANK RES. OBSERVER 117, 117 (1999) (arguing that sound judicial systems are important to economic growth and surveying some current studies). 
The existence of a competent and uncorrupt judiciary is an important institution for the effective functioning of a formal property regime. Without a judiciary that is perceived as competent, individuals will be unlikely to turn to courts to settle their disputes, leading to informal dispute resolution mechanisms, which may not provide individuals with complete legal protection of their property rights. Similarly, where a corrupt and bribetaking judiciary is the norm, the costs of accessing the justice system are significantly raised for individuals. This can also create disincentives for using the formal property regime.

Even where the judiciary is perceived as being competent, honest, and fair, weak enforcement mechanisms can deter individuals from seeking to enforce their rights through the courts. Given the costs associated with litigation, individuals may be loath to litigate disputes if they believe that a favorable judgment will not be enforceable.279 For example, the problem of unenforceable judgments is severe in China. Concerns about enforceability may also influence the judgment itself. This problem has also been documented in China, where courts will be reluctant to make judgments that they believe are politically or socially unenforceable, such as evicting a tenant who has no place to go. ${ }^{280}$

While an independent and effective judiciary is a necessary institution for individuals to be able to enforce their property rights, it is by no means sufficient. Individuals also need the tools necessary to access those courts, i.e., lawyers. Where lawyers are prohibitively expensive and legal aid programs are nonexistent or underdeveloped, poorer property owners may have difficulties enforcing their rights. As noted above, this has been a significant problem in China, where rural farmers have had limited access to justice and thus have difficulty challenging the illegal decisions taken by the collective or local governments. ${ }^{281}$

A functional police force is another institution that plays a critical role in enforcing and realizing the benefits of strong property rights. A strong police force protects private property by deterring and preventing the commission of crimes against property as well as by apprehending those who commit such

279 See Donald C. Clarke, Power and Politics in the Chinese Court System: The Enforcement of Civil Judgments, 10 COLUM. J. AsIAN L. 1 (1996) (describing weak judicial enforcement mechanisms in China).

280 Id. at 33.

281 PEERENBOOM, supra note 129 , at $481-89$. 
crimes. ${ }^{282}$ Where the police are corrupt, individuals may be reluctant to turn to them; lower income households may particularly vulnerable, as not only might they be unable to afford the requisite bribes, they also have the fewest resources to privately enforce their property rights. Similarly, in some states, the police function more as a guarantor of the government's rule rather than as a protector of private citizen's rights. Under these conditions, property rights will effectively be weaker, as individuals will have fewer protections against the theft or vandalism of their property.

\subsection{Concluding Remarks on the Preconditions of a Formal Property Rights Regime}

While the previous Section of this Article concluded that the costs of a formal property rights regime may outweigh its benefits in some circumstances, this Section has sought to emphasize that a formal property regime is intertwined with a number of other social, economic, and legal institutions. An evaluation of the operation and benefits of a formal property regime in a given country also necessarily involves an analysis of these related institutions, as the success of that property regime depends in large part on those institutions. Indeed, this Section suggests that formal property rights institutions cannot simply be grafted onto any state or society. These insights also suggest a number of related conclusions.

The above analysis again demonstrates that there are no easy solutions to questions of economic development. Even if some scholars are correct in asserting that the lack of formal property rights is a major reason for underdevelopment, the creation of a formal property rights regime is likely to require the strengthening or creation of a number of related institutions.

This Section also reaches a similar conclusion to that of the Section 1. Namely, this Section provides support for the proposition that a formal property regime will function more successfully in a more developed state. Where an economy is characterized by the presence of some functioning market institutions, anti-market social norms relating to prohibitions on the transfer of land may be less prevalent or will be more malleable. Moreover, where credit and labor markets are more

282 Stephen Holmes \& CASS R. Sunstein, The Cost OF Rights: Why LiBerTy DEPENDS ON TAXES 63-64 (1999). 
developed and the state has more resources and a greater capacity to provide legal protections, individuals will be more likely to turn to the formal system rather than relying on informal systems. Thus, this suggests that a formal property rights regime will be more likely to function successfully at medium rather than low levels of economic development.

\section{THE PROCESS OF REFORM OF PROPERTY RIGHTS REGIMES}

\subsection{Evolutionary Changes in Property Regimes}

There is a sense in which the formal and informalist positions discussed above do not reflect a stark dichotomy of property rights regimes, but rather general loci along a temporal continuum in the evolution of property rights. Indeed, a prominent view within the law and economics movement is that property rights will evolve in response to an increase in their relative benefits. ${ }^{283}$ On the one extreme of the spectrum is an open-access regime, where land is exceptionally plentiful and the costs of any form of private property rights outweigh the benefits. As the relative benefits of private property increase, communal property rights that exclude outsiders may be a rational response to the economic situation. ${ }^{284}$ As the relative benefits increase further, individual property rights may emerge, with-in an economically efficient world-the optimal degree of formalization occurring where the marginal cost of further formalization equals the marginal benefit derived from increased security and clarity.

While greater privatization and formalization may emerge from more informal regimes as the benefits of such formalization increase and the costs of formalization decrease, it is important to identify precisely the major factors that drive this process.

283 See generally Demsetz, supra note 11, at 350-54 (arguing that property rights emerge in response to new benefit-cost possibilities); ELLICKSON, ORDER WITHOUT LAW, supra note 51 (exploring how in close-knit groups informal norms, akin to property rights, develop to maximize the welfare of the group as a whole); North \& Thomas, supra note 65 (examining the rise of the Western World with a focus on the role of property rights in creating incentives to drive economic growth).

284 See Migot-Adholla et al., supra note 76 (analyzing how an indigenous African tenure system, a communal property system, has responded to changing economic circumstances such as increased population and commercialization pressures). 
Anderson and Hill posit that privatization will increase as a) relative prices change such that the resource becomes valuable, $b$ ) technological advances decrease the cost of enforcing such rights, and c) collective action to enforce and recognize those property rights becomes relatively easier. 285 If such evolution of property rights does indeed naturally occur, it might be the case that there are limits on what outsiders can and should do with respect to promoting property rights arrangements.

In a more recent paper, Demsetz has expanded on his earlier work and identified three major sources of the changes in costs and benefits that have led towards the greater prevalence of private property. ${ }^{286}$ The first factor is the decreased importance of compactness to the overall economy, by which he means that private property will emerge as groups become less close-knit. The second factor is greater productivity; as productivity increases, so does the "societal interest in arrangements that encourage effort and facilitate some sharing of the gains from this effort." 287 The third factor is the increased complexity of resource allocation problems. Demsetz notes that as specialization of labor increases, coordination becomes more difficult. While the price mechanism is a strong decentralized coordination mechanism, it requires a strong degree of certainty to function. This degree of certainty is provided by formal property rights.

Although the above accounts describe the conditions under which such transitions are expected to occur, they largely fail to identify a mechanism by which a transition between property rights regimes occurs. The reasoning underlying much of the work is that such transitions are simply the product of rational individual or coordinated decisions to define and enforce stronger property rights, 288 although some commentators recognize the role

285 Terry L. Anderson \& Peter J. Hill, The Evolution of Property Rights, in PROPERTY RIGHTS: COOPERATION, CONFLICT, AND LAW, supra note 13, at 126-30. Libecap produces a similar list of factors, but the third factor above is replaced by "shifts in preferences and other political parameters." See GARY LIBECAP, CONTRACTING FOR PROPERTY Rights 16 (James Alt \& Douglass North eds., 1989).

286 Harold Demsetz, Towards a Theory of Property Rights II: The Competition Between Private and Collective Ownership, 31 J. LEGAL STUD. S653 (2002).

287 Id. at $\mathrm{S} 663$.

288 Anderson and Hill argue that "the creation of new property rights begins with the heterogeneous entrepreneurial perception of new and different attributes or uses of a resource. To keep the rents from this perception from being dissipated in a tragedy of the commons, the entrepreneur must contract to exclude 
of the state in responding to and formalizing such changes. 289 In general, the prediction here is primarily one of the efficient evolution of social norms with respect to land. Demsetz's prediction is manifested in the norms literature by Ellickson, who hypothesizes that "land rules within a close-knit group evolve so as to minimize its members' costs." 290 Not only will social norms emerge to create order, as discussed above, but furthermore, those norms will evolve efficiently in response to exogenous changes. ${ }^{291}$

There seems to be a significant body of empirical evidence in favor of this general pattern of efficient decentralized evolution. Alston et al. suggest that people have greater incentives to acquire formal title where land values increase, and confirm this in their analysis of the determinants of title registration on the Brazilian frontier. ${ }^{292}$ Micelli et al. show that in Kenya, where there is a system of voluntary conversion from communal trust land to individual ownership, the likelihood of conversion and gaining formal title is strongly dependent on the costs and benefits of doing so. ${ }^{293}$ Even in China, it may be that a process of Demsetzian evolution in property rights is occurring to some extent, subject to political economy considerations and intervention by the central government. Following Demsetz's reasoning, Liu et al. argue and provide empirical support for the proposition that property protections will be strongest in areas which are land scarce (i.e., where the value of the resource is highest), and where there are

others from the value of his perception." Terry L. Anderson \& Peter J. Hill, Cowboys and Contracts, 31 J. LEGAL STUD. S489, S492-93 (2002).

289 LIBECAP, supra note 285, at 10-28 ("The ways in which politicians react to the demands of property owners and their competitors will importantly affect how property rights institutions are formalized and how wealth is distributed.")

290 Ellickson, supra note 15, at 1320. This apparently efficient endogeneity of property regimes has led some to argue that the state should offer a fixed menu of property options in order to strike a balance between the economic efficiency that arises from the ability of individuals to use a number of property regimes, and the transaction costs that occur as the number of property regimes increases. See Thomas W. Merrill \& Henry E. Smith, Optimal Standardization in the Law of Property: The Numerus Clausus Principle, 110 YALE L.J. 1, 3 (2000) (discussing the strict standardization of the legal dimensions of property).

291 ELLICKSON, ORDER WITHOUT LAW, supra note 51.

292 Alston et al., supra note 96, at 57.

293 Thomas Miceli et al., The Demand for Land Title Registration: Theory with Evidence from Kenya, 3 AM. L. \& ECON. REV. 275 (2001). 
significant off-farm opportunities (i.e., where the benefits provided by the insurance function of land are weakest). ${ }^{294}$

Examples of this type of evolutionary process are also available from the developed world. Anderson and Hill, in examining the American West, show how a trend from open access to private property occurred in response to the increasing benefits (greater population density, higher land values) and decreasing costs (the invention of barbed wire) of enforcing individual property rights. ${ }^{295}$ In his discussion of mineral rights in the United States, Libecap chronicles a relatively smooth emergence of property rights, as miners came to agreement relatively quickly about property rights and governments institutionalized these arrangements. ${ }^{296}$ In a different context, the development of water rights in the United States provides support for this thesis, as the relatively water-plenty Eastern states adopted the English system of riparian rights, while in the water-scarce Western states, the more individualized prior appropriation system emerged. ${ }^{297}$ In a study of the reversal of this evolutionary process, Haddock and Kiesling note that because the Black Death significantly decreased the scarcity of land, large amounts of land reverted from private land to open access, as it was no longer efficient to hold such land privately. ${ }^{298}$ If this evolution towards efficiency is a more general phenomenon, then it might be argued that the state's role should be to facilitate, formalize, and enforce a variety of property rights regimes along the lines of those which have evolved in a given society.

294 Shouying Liu et al., Dimensions and Diversity of Property Rights in Rural China: Dilemmas on the Road to Further Reform, 26 WORLD DEV. 1789, 1790-94 (1998).

295 Anderson \& Hill, supra note 196, at 169-72 (discussing the changing circumstances in the open plains that led to an investment in defining and enforcing property rights).

296 LIBECAP, supra note 285 , at ch. 3.

297 Carol M. Rose, Energy and Efficiency in the Realignment of Common-Law Water Rights, 19 J. LEGAL STUD. 261, 265-67 (1990); see also Anderson \& Hill, supra note 196, at 176-78 (describing the riparian rights system that was implemented in as settlers moved into the West).

298 David D. Haddock \& Lynne Kiesling, The Black Death and Property Rights, 31 J. LEGAL STUD. S545 (2002). 


\subsection{Impediments to Evolutionary Regime Change}

There are at least three reasons why this ideal type of evolution may not occur in property regimes. Each of these will be discussed in turn.

\subsubsection{The Property Regime as a Public Good}

First, it may be that certain components of the process of property rights formalization are public goods, which would be underprovided by rational individuals acting independently in the presence of collective action problems.299 For example, a central land registry might provide all registered property-holders with significantly enhanced tenure security compared to a customary tenure system, by reducing land disputes, but no individual property owner has an incentive to invest in creating such a system because of the significant costs involved. Miceli and Keiyah formally model this problem and show that a universally welfareimproving property system is unlikely to be voluntarily adopted by all property owners when there are costs involved, as property owners cannot fully internalize the benefits of the system. ${ }^{300}$

This problem is likely to be more pronounced at higher levels of economic development. At lower levels of economic development where communities are smaller and more close-knit, collective action problems can more easily be overcome through informal norms and practices. ${ }^{301}$ Moreover, the costs of creating and maintaining an informal property regime are lower than that of a formal property regime, thus making collective action problems easier to overcome. Although this collective action problem is likely not a substantial problem in relatively informal property regimes, if a formal property regime is indeed an efficient institution at a certain level of development where the need for security of tenure is relatively high, then the collective action problem is likely to arise eventually.

299 Banner, supra note 197, at S362-64 (discussing the collective action problem that arises when transitioning to a new property rights regime); see also DEININGER, supra note 5, at 23-25 (discussing property rights as a public good).

300 Thomas J. Miceli \& Joseph Kieyah, The Economics of Land Title Reform, $31 \mathrm{~J}$. COMP. ECON. 246 (2003).

301 Banner, supra note 197, at 362. 


\subsubsection{The Inefficiencies in Informal Regime Change}

Certain critiques suggest that norms and informal arrangements might actually be inefficient, at least for certain periods of time. There are three reasons for this. First, with respect to Ellickson's thesis about the evolution towards efficiency of norms in close-knit groups, Eric Posner points out that norms produced in this setting will only be socially efficient for those in the close-knit group itself. ${ }^{302}$ In these circumstances, costs will be externalized as much as possible, meaning that group outsiders can be significantly harmed by such norms. One might imagine manifestations of this in the context of property when dealing with norms that prohibit the transfer of fertile land to group outsiders. Indeed, André and Platteau have shown how increasing scarcity of land in Rwanda has led to the development of tighter restrictions on the customary rights of access to land for certain groups, including return-migrants, widows, and orphans. ${ }^{303}$ In an example from the developed world, Rose argues that a similar phenomenon occurred in the development of British water law. ${ }^{304}$ For a period of time, instead of leading to more formally demarcated private property rights, the increasing scarcity of water resources led to a status quo approach to water management whereby ancient water uses were privileged over newer ones; this represented an effort by previously advantaged groups to maintain their previously allocated water rights to the detriment of newcomers. ${ }^{305}$ As pointed out above, this may be especially problematic in situations where group membership is very inflexible and is supported by family or clan ties, because this may further entrench an otherwise inefficient arrangement. 306

Second, to the extent norms are sticky, reliance on norms may be extremely inefficient when there are significant lags in the adjustment of those norms to rapid exogenous changes, such as

302 Eric A. Posner, Law, Economics, and Inefficient Norms, 144 U. PA. L. REV. 1697, 1698 (1996).

303 André \& Platteau, supra note 78, at 39-41.

304 Rose, supra note 297, at 267-274.

305 Id. at 273.

306 See Fitzpatrick, supra note 220, at 1028-29 (arguing, for example, that "a norm-based system supported by kinship structures is more likely to respond to rising resource values by tightening its governance mechanisms or enhancing exclusionary rights"). 
changes in population or technology. ${ }^{307}$ In the property context, this might suggest that norms which previously governed land use efficiently might lag in changing to significant exogenous changes in population or technology which make land relatively scarce. For example, while informal mechanisms of transferring land have developed, in situations where they were previously non-existent, there may be a significant lag leading to serious inefficiencies. One author has argued that this problem was actually present in Demsetz's case study of the Montagnais Indians, arguing that it took about two hundred years after the exogenous change in factor prices caused by the fur trade to lead to a greater degree of privatization in property relations. 308

Closely related to this problem is the issue of path dependence. It may be that in certain cases, arrangements which have long been inefficient will be preserved by the sheer weight of the myriad social layers and interactions that have emerged under those arrangements. ${ }^{309}$ The initial inefficient arrangement may be reinforced by subsequent actions. As North writes, the "existing institutional structure [creates] organizations with a vested interest in the existing structure." 310 Where switching costs are, or appear to be, sufficiently high, this may prevent organic institutional change. This notion of path dependence may explain the continued existence of some cases of inefficient property arrangements.

Third, Mahoney and Sanchirico provide an alternative critique of the efficiency of norms based on game-theoretic analysis and norm evolution. Using the evolutionary framework employed by Axelrod, discussed earlier, 311 they point out that if the mismatch

307 This lag in regime evolution is likely partially related to the costs of transitioning between regimes. As Banner points out, there may be significant costs in the process of creating a new property rights regime. See Banner, supra note 197, at S362 (explaining that establishing and enforcing a new system of property rights involves significant time and labor). Changes in norms may also be sticky because individuals have internalized a norm and continue to act on it despite its inefficiency. On internalization, see POSNER, LAW AND SOCIAL NORMS, supra note 56, at 43-44 (debunking a variety of legal theories which attempt to explain how law influences social norms).

308 Posner, supra note 302, at 1712-13.

309 For a discussion of various aspects of this path dependence, see DouGLASS C. North, Understanding the Process of ECONOMic CHANGe 51-52, 156-157 (2005).

310 Id. at 160.

311 See supra note 44 and accompanying text. 
risk $^{312}$ of a norm is high relative to the gains from playing efficient strategies, then efficient norms are unlikely to emerge. They note, for example, that both "always defect" and "tit-for-tat" are evolutionarily stable strategies, and that using a slightly different pay-off structure from Axelrod's analysis, and assuming random mutations, it is quite likely for the equilibrium to tip from "tit-fortat" to "always defect," but not vice versa. Thus, they show that the evolution towards efficient norms is highly dependent on the particular costs and benefits of the various arrangements and that such evolution may not occur, even when it would be socially beneficial. 313

\subsubsection{A Political Economy Model of Change in Property Regimes}

Finally, there are some authors who explicitly reject the efficient evolutionary framework in favor of a political economy framework for understanding changes in property regimes. Under this model, changes in property rights regimes occur when groups have sufficient political power to induce a property regime change that benefits their interests. ${ }^{314}$ Libecap similarly notes that decisions about property rights institutions are made through the political process and that influential groups can have a significant impact in determining the property regime, irrespective of efficiency considerations. 315 Because there are costs to creating and implementing a new property regime, relatively small groups will have an incentive to cooperate to facilitate regime changes where the benefits are concentrated in their hands and the detriments are

312 A norm has mismatch risk if it is Pareto optimal when played against itself, but does relatively poorly against disparate norms.

313 Paul G. Mahoney \& Chris W. Sanchirico, Competing Norms and Social Evolution: Is the Fittest Norm Efficient?, 149 U. PA. L. REV. 2027 (2001).

314 See Saul Levmore, Two Stories About the Evolution of Property Rights, $31 \mathrm{~J}$. LEGAL STUD. S421, S421-27 (2002) (claiming that the "prevailing arrangement of property rights may be the product of politics and interest group-activity"). See Jean Ensminger \& Jack Knight, Changing Social Norms: Common Property, Bridewealth, and Clan Exogamy, 38 CURRENT ANTHROPOLOGY 1, at 4-5 (1997), for a survey of the competing positions of efficient norm evolution and norm evolution as triggered by distributional benefits. See also Daron Acemoglu et al., Institutions as the Fundamental Cause of Long-Run Growth (Nat'l Bureau of Econ. Research, Working Paper No. 10481, 2004), available at http:/ / www.nber.org/ papers/W10481.pdf, for a historical analysis which argues that property rights arrangements are primarily determined by political considerations.

315 LIBECAP, supra note 285 , at 4-5. 
widely dispersed among a large segment of the population. ${ }^{316}$ Sonin provides an alternative model that suggests that the rich may favor poor property rights protection. Because of their wealth, the rich may be able to provide private protection for their own property while using that same private enforcement power to expropriate others' ${ }^{317}$ Thus, under a political economy framework of property rights, there is no reason to believe that property arrangements will naturally evolve towards efficient institutions; indeed, under certain circumstances, the reverse may occur.

Moreover, even where changes to the property regime would be efficient, under a bargaining or political economy framework of property rights, difficulties in bringing about those changes may lead to an inefficient status quo bias. To the extent that significant agreement is required among different members of a group for changes in property regimes to take place, certain group characteristics might make such consensus harder to achieve. As Libecap notes, as the number of interest groups increases or the heterogeneity of the interest group's preferences increases, agreement will be more difficult to achieve. ${ }^{318}$ Libecap argues that the presence of large numbers of heterogeneously-skilled fisherman was a major impediment to the development of efficient property arrangements in American fisheries. 319

There is some evidence that political economy explanations have some degree of validity when applied to questions of Chinese property reform. Some authors have argued that village leaders play an important role in designing property arrangements for their villages. Recognizing that a diversity of arrangements exist throughout China, Rozelle and $\mathrm{Li}$ argue that a village leader's choice of a particular property regime will depend not only on the general benefits to the village, but also on the personal interests of

316 See Banner, supra note 197, at S369 (recognizing that “[a] relatively small number of people who anticipate disproportionately large gains from a transition will have a greater incentive to cooperate in organizing the transition than would a larger number of people anticipating gains more equally distributed"); LIBECAP, supra note 285, at 5-6 (discussing the need for share concession or a side payment scheme to compensate those who would otherwise oppose property right change).

317 Konstantin Sonin, Why the Rich May Favor Poor Protection of Property Rights, 31 J. COMP. ECON. 715 (2003).

318 See LIBECAP, supra note 285, at 21-24 (examining factors that influence political conflict over distribution and the likelihood of agreement on institutional change).

319 Id. at ch. 5. 
the leader, as well as the administrative cost of administering a given system. ${ }^{320}$ Such political economy considerations might also help explain certain elements of the 2007 Property Law, which provided certain concessions to the increasingly politically important urban middle class - such as rights to parking spaces for urban dwellers - while arguably changing little for rural farmers.321

\subsection{Responding to Evolutionary Failure: The Role of Outsiders}

It is important to note that these different impediments to the Demsetzian evolution of property rights call for different responses from outsiders in helping to craft reforms for property rights regimes in developing countries. These responses point to the fact that a one-size-fits-all solution to creating efficient property arrangements is unlikely to be successful. From a policy perspective, when outsiders identify a state in which an alternative property arrangement would be more efficient than that already in place, a necessary prerequisite to an effective plan for remedying that inefficiency is an understanding of why that inefficient arrangement has persisted.

If property arrangements have reached a point of sufficient formalization such that certain aspects of the property regime have the characteristics of a public good, then the role for outsiders is largely limited to providing sufficient resources to the state in question to allow it to overcome this collective action problem. Expert advice may also be required to help those states with the challenge of designing and implementing a formal property regime. Resources and advice may also be required to help those states bolster other complementary institutions. In these circumstances, once the resources and expertise are provided, the new property arrangement should be quickly adopted, because, by hypothesis, the aggregate benefits to individuals of such private property rights will outweigh the costs.

Where the informal evolutionary regime of property arrangements has become inefficient, a much more active role is required by both the state and outsiders to create an efficient property regime. The first and most obvious challenge is

320 Scott Rozelle \& Guo Li, Village Leaders and Land-Rights Formation in China, 88 Am. ECON. ReV. 433 (1998).

321 Property Law, supra note 115. For a critique, see ECONOMIST, supra note 115 (describing the critiques of the left that consider the 2007 law to be unconstitutional). 
determining that a particular set of norms is inefficient. Posner lists five situations in which the state should take action because of inefficient norms:

(1) If the group members tell the state, or its agents, that the norm is inefficient or change is desired.

(2) If there is extensive bargaining around a norm.

(3) If there is rapid economic or technological change. ${ }^{322}$

(4) If there are highly unequal endowments of group members.

(5) If the state detects inefficiencies before the group does. ${ }^{323}$

Once an inefficient arrangement has been identified, the problem remains of crafting an appropriate and efficient solution as well as a strategy for implementing that solution. As above, this may involve significant amounts of financial support and expertise. However, in contrast to the first scenario discussed above, policymakers face the additional hurdle of ensuring that the inefficient norms that the new formal system seeks to eliminate do not instead render that system ineffective. Thus, any new system must be sensitive to existing social norms regarding property. As discussed above, not only must the new system be obviously superior to existing norms, but moreover, the new system must be perceived to be accessible at low cost relative to its benefits, and, when involving mechanisms that entail marked changes from entrenched social norms, should be introduced gradually or on a voluntary basis. 324

While the successful implementation of new property arrangements by either the state or outsiders may be difficult

322 This is precisely the situation in which André \& Platteau suggest the state should intervene. See André \& Platteau, supra note 78 (describing the rapid economic changes in Rwanda resulting in unequal land distribution, rising social tensions, and ultimately contributing to the civil war in 1994).

323 Posner, supra note 302, at 1726-27 (suggesting ways in which the state may identify inefficient norms).

324 See supra text accompanying notes 254-256, 271-275; see also Thrainn Eggertsson, Open Access versus Common Property, in PROPERTY RIGHTS: COOPERATION, CONFLICT, AND LAW, supra note 13, at 73, 77 (discussing the economic consequences of open access on both the supply and demand side); Michael J. Trebilcock, Comment on "The Rule of State Law and the Rule-of-Law State: Economic Analysis of the Legal Foundations of Development," by Robert D. Cooter, in ANNUAl WORLD BANK CONFERENCE ON DEVELOPMENT ECONOMICS 1996, at 229 (Michael Bruno \& Boris Pleskovic eds., 1997) (discussing incentives of governmental and economic actors to switch to new norms). 
where inefficient norms are relatively stable and effective for at least certain groups, the case for active intervention is much stronger where land governance norms are breaking down. Extremely rapid changes in land scarcity have in some cases also led to increased land conflict, as inefficient norms have broken down without new norms emerging to replace them. In these circumstances, litigation or more violent means have consumed significant resources in resolving disputes,, 25 and there may be a significant role for the government or external actors to identify such problems and craft appropriate solutions.

While the above discussion optimistically suggests that the first two impediments can largely be overcome through the provision of resources and expertise, where an inefficient arrangement exists because of political economy considerations, no simple solution exists. Where an existing inefficient property arrangement benefits certain actors, those actors will resist attempts to change that regime. If the state is exceptionally weak or is captured by those actors who benefit from the inefficient regime, then the provision of resources or expertise is likely to have no impact, as the state will be unwilling or unable to use those resources to implement the new property regime. Under such circumstances, a successful property regime change would require either strengthening those groups in favor of the reform, or convincing elites to accept changes either through rewards or sanctions. Although this is not the appropriate context to elaborate or propose theories of the political economy of property rights reform, the point remains that under these circumstances, the introduction of formal property rights would be significantly more difficult and could not be accomplished by even the best-designed World Bank titling program.

\footnotetext{
325 On Kenya, see Barrows \& Roth, supra note 77 for a discussion on land tenure and investment in African agriculture. On Rwanda, see André \& Platteau, supra note 78, which describes the rapid economic changes in Rwanda resulting in unequal land distribution, rising social tensions, and ultimately contributing to the civil war in 1994. See also DeININGER, supra note 5, at 35 (discussing how disputes over land create a myriad of negative impacts and consequences); Fitzpatrick supra note 220, at 1031-33 (explaining how an inability to prevent resource use from outside groups can result in norm-based regime deterioration and intercommunity conflict); Karim Hussein et. al., Increasing Violent Conflict Between Herders and Farmers in Africa: Claims and Evidence, 17 DEV. POL'y REV. 397 (1999) (discussing competition and violent conflict over natural resources between herders and farmers in Africa).
} 


\subsection{Concluding Remarks on the Process of Reform of Property Rights Regimes}

While the discussion of the first two questions raised in this Article adopted a static approach to the examination of property regimes, this Section has adopted a dynamic approach and examined potential paths for the development of property regimes over time. As in the above Sections, this Section suggests that the issue of whether outsiders should support the creation of a formal property rights regime is far from clear. The lack of a strong formal property regime in a given state may represent a lack of resources or some other evolutionary failure which calls for the assistance of outsiders. However, the absence of a formal property regime may also simply reflect the fact that such a regime would be inefficient in the circumstances. Thus, an analysis of whether or not a titling program would benefit a given state necessarily involves understanding why a formal property system does not yet exist in that state.

Moreover, as highlighted extensively in the preceding Section on the preconditions for a formal property rights regime, this Section has further demonstrated that the success of a formal property rights regime is highly dependent on the context. The same impediments blocking the efficient evolution of the property regime can also operate to render ineffective those very programs which attempt to overcome those hurdles. It cannot simply be presumed that the external provision of funding or expertise to create the framework of a formal property regime will be sufficient to ensure its successful adoption. Indeed, the same costs, inefficient social norms, or political interests that precluded the endogenous development of a formal property rights regime may similarly hinder the successful operation of that regime even after the institutional framework of that regime has been created.

\section{CONCLUSION}

The above discussion has highlighted many of the issues surrounding property rights and development. Because of the complex interactions between a property rights regime and the social, economic, political, and legal framework within which such a regime operates, it is not fruitful simply to argue for or against the formalization of a property rights regime. Rather, the relationship between property rights and development is much more complex, and a more nuanced approach to these issues is 
required. As North writes, "[t]he first requirement for improving economic performance is to have a clear understanding of the sources of poor economic performance." 326 This statement certainly applies to the relationship between property rights and economic performance.

The context-dependence of successful property regimes leads to three important considerations. First, property formalization programs must not be considered as isolated economic development projects as one might consider certain physical infrastructure projects. Rather, such programs must be considered as part of a general framework for economic development, typically including a wider set of reforms aimed at the promotion of the rule of law. ${ }^{327}$ Contrary to the optimistic rhetoric of De Soto's work, 328 property formalization programs are not by themselves the key to unlocking the potential of the developing world. While a formal property regime may be a necessary condition for economic growth beyond a certain level of development, it is by no means sufficient.

Second, in determining what role outsiders can play in helping promote a state's formal property regime, it is essential to ask a broader question about the similarities between optimal property regimes. If the optimality of a property rights regime is contextindependent, then a titling program developed by theorists in Washington or from elsewhere in the developed world may indeed be applicable and beneficial to extremely diverse countries. However, because the characteristics of a property regime are highly dependent on local context, it is unrealistic to expect that one model of a successful regime would be applicable across various states. In fact, one would expect that the characteristics of property regimes as well as strategies for their implementation will differ substantially across states. This suggests that, in practice, local or regional models of property regimes may be more successful than Western models. ${ }^{329}$

326 NORTH, supra note 309, at 163.

327 DAM, supra note 1, at ch. 10 (examining the implications of a rule-of-law approach to economic development).

328 DE SOTO, supra note 7.

329 For recent work on this notion see Sharun W. Mukand \& Dani Rodrik, In Search of the Holy Grail: Policy Convergence, Experimentation, and Economic Performance, 95 AM. ECON. REV. 374 (2005), which argues for implementation of appropriate policies and institutional arrangements on the local level. 
Finally, significant changes to property regimes should be approached with caution and drastic, uniform top-down property changes should be avoided.330 Contrary to conventional economic thinking, the formalization of property rights is not necessarily desirable at all stages of development or for all property owners. Formalization programs can have far-reaching social and economic consequences, and under certain conditions, formalization programs can have negligible or deleterious impacts. The contextspecificity of property rights regimes is not, however, a reason for inaction or a reason to counsel against the formalization of property rights in all cases. As noted above, under some circumstances, formal property rights have increased efficiency and led to economic growth, and it would thus be poor policy never to support the formalization of property rights.

Because of these considerations, unless there is clear and compelling evidence pointing to the need for a systematic state-led formalization program, the optimal response may be a voluntary and sporadic system of title registration. Although a sporadic program of title registration is not without its own costs, 331 such a program brings substantial benefits relative to a systematic formalization program. As one of the Authors has argued elsewhere, in the face of limited resources and state capacity, a sporadic system of land registration has the benefit of providing the additional security and clarity of formal property rights to those desiring it most. ${ }^{332}$ By simply providing an additional vehicle for owning property, a sporadic registration program does not require disturbing the arrangements of those groups that are content with the status quo. Where customary arrangements limit individuals' economic opportunities, the option of formalization is present. These characteristics suggest that such a system can operate as the backbone of an efficient Demsetzian evolution of property regimes. Moreover, a voluntary system overcomes the collective action problem of providing the machinery for the

330 For a classic paper exploring the importance of avoiding drastic imposed changes see Charles E. Lindblom, The Science of "Muddling Through," 19 PUB. Admin. Rev. 79 (1959). See also James C. Scott, SeEING LiKe A State: How Certain SCHEMES TO IMPROVE THE HUMAN CONDITION HAVE FAILED (1998).

331 Trebilcock, supra note 201, at 412 (using the example of Papua New Guinea to elucidate the costs that accompany a sporadic program of title registration).

332 Id. at 412-413. 
enforcement of those property rights by having the state provide it and allowing people to opt into it.

Perhaps the strongest benefit, however, of a sporadic and voluntary formalization system is that it avoids the myriad unforeseeable and potentially negative consequences that can result from the top-down imposition of a uniform system of property arrangements. As this Article has stressed repeatedly, a property rights regime is not an isolated institution, but rather an institution which has strong interrelationships within a variety of other institutions. In such circumstances and where policymakers have imperfect or limited information, it may be impossible to predict all the potential consequences flowing from drastic institutional changes, and unpredictable negative consequences may emerge from imposed changes. ${ }^{333}$ A gradual and reversible process of voluntary change at the individual level can mitigate such potentially harmful consequences.

Even in situations where a systematic program is clearly superior to a voluntary program, drastic and irreversible changes should be avoided. Rather, changes should be incremental in nature. For example, where communal property is prevalent, rather than registering individual titles to specified plots of land to the exclusion of all others, a rudimentary titling program could be undertaken utilizing simple compass and chain rather than fullscale cadastral surveys where only the base group title would be registered without prejudice to the various functional rights that others might possess under customary law. Landowning groups might also be given a more formal legal structure and clearer decision or governance rules (akin to private corporations with restrictions on share transferability), while maintaining limits on outright alienability of group land. ${ }^{334}$ Such programs lessen the potential for serious social conflict or disruption from abrupt legal change and facilitate an evolutionary process for the emergence of strong private property rights.

333 For interesting examples relating to this point, see SCOTT, supra note 330. See also Rachel E. Kranton \& Anand V. Swamy, The Hazards of Piecemeal Reform: British Civil Courts and the Credit Market in Colonial India, 58 J. DEV. ECON. 1 (1999) (discussing how reform led to increased competition among lenders, and the resulting effects on the farmers of India).

334 See generally Fitzpatrick, supra note 242 (discussing the circumstances in which different models of property rights may work); Trebilcock, supra note 201 (discussing various approaches to the phenomenon of communal land rights evolving to private property). 
